\title{
Uluslararası Tahvil Piyasasının Ekonomi Üzerindeki Etkisi; G7 Ülkeleri Örneği ${ }^{*}$
}

\author{
Asef YELGHI*
}

\section{Öz}

Tarih sürecinde finansal sistemin sağladı̆̆ı avantajlar, ülke gelişimine katkı sağladığını göstermektedir. Ülkelerin bu gelişiminde özellikle günümüzün finansal sisteminde, tahvil piyasasının gelişiminin hızlanması, ekonominin büyümesinde önemli olanak sağlamaktadır. Biz bu çalışmada bu etkiyi ölçmek için tahvil piyasasını uluslararası boyutu içerisinde devlet ve özel sektör bazında değerlendireceğiz. Çalışmada G7 ülkelerinin verilerini karşılaștırmalı bir analiz çerçevesinde değerlendirdik. Araștırmada GSYİH bağımlı değișken ve uluslararası devlet tahvili ve uluslararası özel sektör tahvili, bağımsız değișkenler olarak seçilmiștir. Veriler 2000Q12017Q4 dayanmaktadır ve iki aşamalı değerlendirme yapılmıștır. İlk aşamada verilerin mevsimsel olması ve kısıtlı, uzun dönem analiz gerektirmesinden dolayı, Pesaran ve Shin (1999), tarafindan geliștirilen Autoregressive Distributed Lag (ARDL) sınır testi uygulanmıştır. Kısa dönem analizi için VAR-Granger-Causality (Block Exogeneity Wald Tests) analizi kullanılmıştır. Sonuç olarak G7 ülkeleri uluslararası tahvil gelişimi kısa dönemde ülke ekonomisine katkı sağlamamıștır ama uzun dönemde, Japonya ve İngiltere hariç, ekonomiye katkıda bulunmuştur.

Anahtar Kelimeler: Ekonomi Büyüme, Finansal Sistem, Tahvil Piyasasl, Uluslararası Devlet Tahvil Stoku, Uluslararası Özel Sektör Tahvil Stoku, G7 Ülkeleri

\section{Impact of International Bond Market on the Economy; The Case of G7 Countries}

\begin{abstract}
Historical process in most of the countries shows that the opportunities provided by the financial system are strongly efficient in the development of a country. In this development, especially in today's financial system, the acceleration of the development of the bond market may provide an important break for the growth of the economy. In this study, we will try to measure this impact. For this aim, we will evaluate the bond market in terms of the government and private sector within the international framework. We will evaluate the data of G7 countries in a comparative analysis. In the

\section{Özgün Araştırma Makalesi (Original Research Article)}

Geliş/Received: 10.09 .2019

Kabul/Accepted: 26.10 .2019

DOI: http://dx.doi.org/10.17336/igusbd.618201

* Bu makale, 2017 tarihinde Prof. Dr. Ahmet Aksoy danışmanlığında hazırlanan “Türkiye ve G20

Ülkelerinin Karşılaştırmalı Analizi” konulu doktora tezinden üretilmiştir.

${ }^{* *}$ Doktora Öğrencisi, Ankara Hacı Bayram Veli Üniversitesi, Lisans Üstü Eğitim Enstitüsü, İşletme Bölümü, Ankara, Türkiye, E-posta: asefyelghi1365@gmail.com, ORCID ID https://orcid.org/00000003-0683-7218
\end{abstract}


research, GDP dependent variable, international government bonds and international private sector bonds were selected as independent variables. Data's of this study based on 2000Q1-2017Q4 databases and we performed two-stage on it. Due to the seasonal, limited and long term data's, we examine the ARDL model which based on Pesaran and Shin (1999) theory. For short-term analysis, we used VAR-Granger-Causality (Block Exogeneity Wald Tests) model. As a result, the international bond development of G7 countries did not contribute to the national economy in the short term; but long-term this contribution was efficient into the economy, except Japan and the United Kingdom.

Keywords: Economic Growth, Financial System, Bond Market, International Government Bond Stock, International Private Sector Bond Stock, G7 Countries

\section{GíRiş}

Günümüzde ülkelerin, bütçe açığı gibi finansal ihtiyaçlarının giderilmesi için hükümet tarafından tahvil ve bono gibi finansal araçları kullanmaları yaygın hale gelmiştir. Devlet tarafından tahvil ihracı yaklaşık 500 yıl önceye dayanmaktadır ve ilk kez Amsterdam șehrinde ihraç edilmiștir. Daha sonra ise İngiltere, Fransa'ya karşı savaşı finanse etmek için tahvil ihraç etmiştir. Önceden, özel sektör firmaları finansman ihtiyacını karşılamak için kredi kullanırken ya da sermaye piyasasında hisse senedi ihraç ederken, günümüzde tahvil piyasasından fon sağlamaya başlamıștır. Bu finansman sağlama araçlarının özellikleri itibariyle farklı avantajları bulunmaktadır. Aynı zamanda finansal piyasadaki alternatif araçların çoğalması durumunda daha güçlü bir rekabet ortamının ortaya çıkacağı bilinmektedir.

Araştırmada çalışmanın önemi, konu ile ilgili araştırmalar, tahvil ile ekonomik büyüme arasındaki ilişki, araştırma yöntemi ve araştırma bulguları başlıklar altında incelenecektir. Finansal sistem içinde hisse senedi ve bankacılık piyasaları aktif bir şekilde finansal kaynak sağlama fonksiyonu üstlenirken son dönemde özel sektör tahvil piyasası da aktif hale gelmiștir.

Sanayileșmiş ülkeler, ekonomi politikaları koordinasyonu sağlamak amacıyla 1975 'de Almanya, Fransa, İtalya, Japonya, İngiltere ve ABD ülkelerinin bir araya gelmesi ile kurulan G6, 1976'da ise Kanada'nın katılımı ile G7 ülkeleri olarak tanımlanmıştır. Bu çalışmada G7 ülkeleri ele alınarak uluslararası tahvil piyasası ile ekonomik büyüme arasındaki ilişki incelenecektir.

Hisse senedi ve bankacılık piyasasının ekonomik büyüme ile ilișkileri üzerine birçok akademik çalışma bulunmaktadır. Ancak tahvil piyasası, özellikle özel sektör tahvil piyasası üzerine çok az çalışıldığı görülmektedir. Tahvil piyasası ulusal ve uluslararası boyutta değerlendirebilir. Konunun genişliği ve standart verilere ulaşılabilir olması bakımından çalışmamız uluslararası boyutta değerlendirilmek üzere sınırlandırılarak ele alınmaktadır. Çalışmamızda ilk amaç, "uluslararası tahvil piyasasının gelişimi ekonomik büyümeye katkı sağlar mı" sorusuna bir cevap aramaktır. Bunun için devlet ve özel sektörün uluslararası tahvil piyasasında borçlanmasının ülke ekonomisini hangi yönde etkilediği belirlenmeye çalışılacaktır. İkinci amaç ise G7 ülkeleri örneği üzerinde, uluslararası devlet tahvil stoku ve uluslararası özel sektör tahvil stoku ile GSYİH arasındaki ilişkiyi karşılaştırmalı olarak analiz etmek ve çıkarımlar yapmaktır. 


\section{Çalışmanın Önemi}

Küreselleșme ile birlikte ülkeler, uluslararası piyasalarda faaliyet göstermeye başlamıştır. Çalışmada gerek devletin, gerekse özel sektörün uluslararası piyasada faaliyet göstermesinin ülke ekonomileri üzerine etkisi araştırılacaktır. Tahvil piyasasının hızlı gelișimi, kredi piyasalarına göre finansal kaynak sağlama maliyeti açısından rekabetçi ortamda bulunması, devlet ve özel sektör için önemli alternatif finansal kaynak olmuștur.

Tahvil piyasasının gelișiminde, fon arz edenler ile fon talep edenler arasındaki etkileşiminin hızlanması ve piyasa yapılarına göre tahvil türlerinin geliștirilmesi ile önemli bir alternatif finansal kaynak ortaya çıkmaktadır. Buna göre, tahvil piyasasının büyümesi, finansal kaynak sağlamanın katı yapısından ılımlı yapıya dönüşümü sağlayabilir.

Bu çalıșmanın diğer çalıșmalara göre birinci farkı, G7 ülkelerinin tahvil piyasaları ile ekonomik açıdan büyümeleri ilişkisinin ülke bazında incelenmesidir. İkinci fark, uluslararası tahvil piyasasında gerek devlet, gerekse özel sektörün faaliyet göstermesinin, ülkelerin büyümelerine katkı sağlayıp sağlamadığının araştırılmasıdır. Üçüncü fark, devlet ve özel sektörün büyüme üzerinde hem ayrı, hem de birlikte etkilerinin analiz edilmesidir. Aynı zamanda bu analizler, kısa ve uzun dönemi kapsayarak farkı metotlarla gerçekleștirilmiștir. Dördüncü fark ise literatürde finansal piyasalarla ilgili birçok çalışmanın hisse senedi ve bankacılık sektörüne dayalı olması, tahvil piyasasının büyümesi ile ekonomik büyüme arasındaki ilişkiyi inceleyen çok az çalışma bulunması açısından literatüre sağladığı katkıdır.

\section{Konuyla İlgili Araştırmalar}

Ekonominin büyümesinde finansal gelişimin önemini ilk defa Schumpeter (1911) vurgulamıștır. Buchanan (1958) çalışmasında, finansal gelişimi kısa dönem ve uzun dönem olarak kategorize etmiş ve finansal yapıları incelemiştir. Çalışma sonucunda kamu tarafından borçlanmanın verimli olmadığı ve özel sektör tarafından borçlanmanın yarattığı etkiye benzer bir etki yarattığını belirtmiş̦tir. Diğer taraftan ise kamu borçları hem iç piyasada, hem de dış piyasada benzer etki ortaya koymaktadır.

Patrick'e (1966) göre, finansal piyasalar iki kanal ile ekonominin büyümesine sebep olabilir: Birincisi reel sektörün gelişmesi sonucunda, finansal piyasaların gelişmeye gereksinim duymasıdır ve bu büyümeye "talep izleyici" adı verilmektedir. İkincisi ise finansal kuruluşlarının topladıkları fonları ihtiyaç duyan ekonomik birimlere yönlendirmesi ile ekonomik büyümeyi uyarmasıdır ve bu büyümeye "arz öncüllügü̈" adı verilmektedir. Dolayısıyla finansal aracı kuruluşlar, fon talep edenler ile fon arz edenler arasında bir aracı fonksiyonu ortaya koymakta olup ekonomik büyüme için de önemlilik arz etmektedir (Goldmith: 1969). Fin ve diğerlerine (2003) göre, finans sektörü ile reel sektör arasındaki ilişkide arz öncülü, talep öncülü, birbirleriyle bağll, herhangi bir ilişki olmaması ve negatif ilişki seçenekleri olduğunu varsayabiliriz.

Finansal piyasaların gelişimi ve ekonomik büyüme ile ilgili çok sayıda araştırma mevcuttur ancak yeni ekonomi teorilerinde, "bir ekonomi dișsal teknolojik ilerlemenin yokluğunda nasıl büyüme sağlayabilir" sorusu üzerinde durulmaktadır. Bu çerçevede finansal piyasalarının ekonomik büyümeye katkı sağlayabileceği düşünülmektedir (Pagano: 1993).

Birçok çalışmada, finansal piyasaların gelişimi ile ekonomik büyüme arasında pozitif ilişski olduğu sonucuna varılmıștır. Örneğin Gurley ve Show (1955), Goldsmith (1969), McKinnon (1973), Levine (1997), Fry (1978), King ve Levine (1993), Levine ve diğerleri (2000), Demirgüç-Kunt ve Levine (2001), Graff (2001), Trew ve Andrews 
(2005), Papaioannou (2007), finansal piyasaların gelişimi ile ekonomik büyüme arasında ilişkinin olumlu olduğunu inceleyen çalışmalardır. Ancak Rabinson (1952), Lucas (1988), Deidda (2006) gibi az sayıda çalıșma, finans gelișimi ile ekonomi büyüme arasında olumsuz ilișki olduğu belirtmiștir.

Özel sektör fon sağlama ihtiyacını ağırlıklı olarak iki șekilde gidermektedir: Bankacılık piyasasından sağlanan fonlar ve hisse senedi satışı ile sağlanan fonlar. Söz konusu iki sektör ile ekonomik büyüme arasında yapılan çalışmalar şu şekildedir: Levine ve Zervoz (1996), hisse senedi piyasası ile ekonomi büyüme arasındaki ilișkiyi araştırdıklarında pozitif ilişki olduğu ortaya çlkmıştır. Hermes ve Lensink (2000) çalışmalarında, hisse senedi piyasası ve bankacıllk sektörünün ekonomiye katkı sağladığını göstermişlerdir. Kenourgios ve Samitas (2007) Polonya ülke örneğinde, özel sektöre verilen kredilerin ekonominin büyümesinde önemli rol oynadığı sonucuna varmaktadır.

Klasik ekonomi düşüncesine göre, tahvil bir borçlanma aracıdır ve devletin borçlanması ülke ekonomisi ve toplum refahını olumsuz etkileyebilir. Borçlanma yolu ile ülkedeki harcamaların verimli kanallarla finanse edilmemesi durumunda, ülkelerin sermayelerini etkin bir şekilde kullanamamalarına neden olabilmektedir (Gürdal ve Yavuz: 2015).

Tahvil piyasasının ekonomik büyüme üzerindeki etkisini Thumrongtive ve diğerleri (2013) çalışmalarında incelemiştir. Araştırmada 1989-2010 yılları arası 38 ülke verileri kullanılarak regresyon analizi yapılmıştır. Sonucunda hisse senedi piyasasının gelişimi ile ekonomik büyüme arasındaki ilişkinin pozitif olduğu; banka kredisinin ekonomik büyümeye katkısının yerel tahvil piyasaları geliştikçe azalmakta olduğu ve devlet tahvilleri ile ekonomik büyüme arasındaki ilişkinin pozitif olduğu ortaya çıkmıştır. Massa ve Zaldokas (2013), ABD'li firmaların uluslararası ve ulusal tahvil ihraçlarının, yatırımcılar tarafından tercih edilme durumunu incelemiştir. Çalışmada uluslararası yatırımcıların tahvil taleplerinin arttığı görülmüștür. Ayrıca uluslararası tahvil ihraçlarının verim spreadlerinin, ulusal tahvil ihraçlarının verim sprealerinden daha düşük bir seviyede olduğu ortaya konmuştur. Sonuç olarak 19982006 yılları arası, ABD firmalarının uluslararası tahvil ihraç verileri incelediğinde, uluslararası piyasalardan daha düșük maliyetli ve daha büyük miktarda fon sağlama imkânı sunduğu görülmüştür. Ayrıca ABD şirketleri, ulusal kredi piyasasında doyum noktasına ulaştığı için uluslararası borçlanmaya gidildiği görülmüştür.

Çalışmalardan bir diğeri ise, Asya Banka Gelişim Enstitüsü’nün 1998-2008 yılları arası Asya ülkeleri tahvil piyasasının ekonomik büyüme üzerindeki etkisini araștırdığı çalışmadır. Çalıșmanın sonucunda GSYH'si ile devlet ve özel sektör tahvili arasında pozitif ilişki ortaya çıktığı görülmektedir (Asian Development Bank Institute: 2001).

Fink ve diğerleri (2003), tahvil piyasası ile ekonomik büyüme arasındaki ilişkiyi incelemişlerdir. Çalışmada 13 gelişmiş ülkenin 1950-2000 yılları arasını kapsayan dönem verileri ele alınmıștır. Japonya, Finlandiya ve İtalya gibi ülkeler, tahvil piyasasının gelişimi ve reel üretim artışı arasındaki karşılıklı bağımlılığı ortaya koymaktadır. Chowdhury ve diğerleri (2013), 2005-2009 yıllarını veri alarak 25 gelişmekte olan ülkenin bazı makroekonomik değişkenlerinin tahvil endeksi üzerine etkisini araștırmıștır. Çalışmanın sonucunda, yayılmıș tahvil endeksi ile doğrudan yatırımlar ve enflasyon arasında pozitif ilişki bulunurken; tahvil endeks yayılımı ile GSYIH ve toplam dış borçlar rezerve oranı arasındaki ilişki negatif olmaktadır. Kapingura ve Makhetha (2014), Güney Afrika'nın 1995-2012 yılları arasındaki tahvil piyasası gelişimi ile ekonomik büyüme arasındaki nedensellik ilişkisini araştırmıştır. Çalışmada Granger eşbütünleşme ve iki Granger testi sonucunda, iki değişken arasında uzun dönem ilişki olduğu ortaya çıkmıştır. Ayrıca ekonomik büyüme olarak gayri safi yurt içi hasılanın, tahvil piyasasının gelișiminden etkilendiği ortaya koyulmuştur. Grjebine ve diğerleri 
(2014), şirketlerin borçlanma yapısı ile ekonominin gelişimini incelemişlerdir. Çalışmada 1989-2013 yılları arasında ele alınan 25 ülkedeki firmaların borçlanma yapıları araştırılmıştır. Sonuç olarak, tahvil ihracının yükselmesi ve tahvillerin kredi yerine bir alternatif hale gelmesinin ekonomideki durgunluktan çıkma hızını artırdığı görülmüştür.

Pradhan ve diğerleri (2015), tahvil piyasasının gelişimi ve ekonomik büyüme arasındaki ilișkiyi incelemiștir. Bu çalışmada G20 ülkelerinin 1990-2011 dönemini kapsayan verileri VAR modeli kullanarak analiz edilmiștir. Analizin sonucunda ise tahvil piyasası gelişimi ile büyüme arasında hem tek yönlü, hem de iki yönlü nedensellik olduğu tespit edilmiştir. Araştırmanın sonucunda, tahvil endeksi ile enflasyon ve doğrudan yabancı yatırımlar arasında pozitif ilişki bulunurken; GSYİH ve toplam dış borç arasında negatif bir ilișki bulunmuștur. Ogboi ve diğerleri (2016), Nijerya'nın 19822014 yılları arasındaki tahvil piyasanın gelişimi ve ekonomik büyümesi arasındaki ilișkiyi incelemiştir. Çalışmanın sonucunda ise istatiksel olarak pozitif ve anlamlı bir ilișki olduğu ortaya çıkmıștır.

Literatür taramasında, tahvili bir finansal araç olarak nitelendirdiğimizde, ağırlıklı olarak finansal piyasaların gelişimi ile ekonomik büyüme arasında pozitif ilişki olduğu görülmüştür. Ancak her ülkenin kendine özgü ekonomik durumu ve sermaye piyasası yapısına göre pozitif ve negatif etki yaratabilmektedir.

\section{Araştırma Yöntemi}

Çalışmada G7 ülkelerinin GSYIH, Uluslararası Özel Sektör Tahvil Stoku "TUOSTS" ve Uluslararası Devlet Tahvil Stoku "TUDTS" değişkenleri 2000-2017 yıllar arası çeyrek dönemler halinde verileri kullanılacaktır. Veriler BIS ve OECD resmi sitelerinden alınmıştır. G7 ülkeleri ekonomileri üzerinde GSYIH ile TUDTS ve TUÖTS arasında kısa ve uzun dönem ilişkiyi test etmek için ana analiz metodolojisi olarak, Pesaran ve Shin (1999), Pesaran ve Shin (2001) tarafından geliştirilen Autoregressive Distributed Lag (ARDL) sınır testi uygulanmıştır. ARDL modeli Yt gibi bir denklemin p sırası dıșsal VAR modelini temsil etmektedir. Bu araştırmada GSYIHt $=\mathrm{f}$ (TUDTSt, TUÖTSt) gibi düşünülebilir. ARDL diğer eşbütünleşik metotlara göre bir kaç önemli avantaja sahiptir: Birincisi, ARDL modelinde bütün değişkenlerin aynı seviyede entegre veya durağan olması gerekmemektedir. Yani değişkenler I(0) ve I(1) seviyelerinde durağan olmalarının test üzerinde herhangi bir sakıncası yoktur. İkincisi, küçük ve sınırlı veri seti örneklerinde ARDL testi daha iyi sonuçlar sunmaktadır. Üçüncü avantaj ise ARDL modeli uzun vadeli analizlerde tarafsız tahminleri sunmaktadır. Ayrıca bu model otokorelasyon problemlerini ortadan kaldırmaktadır. Bu araştırmada verilerin, 2000Q1-2017Q4 arası mevsimsel veriler oldukları, kısıtlı ve uzun dönem analiz gerektirdiği için ilk aşamada bu metot seçilmiştir. Kısa dönem analizi için VAR-Granger-Causality (Block Exogeneity Wald Tests) analizi kullanılmıștır. Bu nedenle normal Granger testi gecikme uzunluğuna çok duyarlıdır. VAR modeli kullanarak en optimum gecikme sayısını belirlemek mümkündür. Aynı şekilde VAR modeli bütün değişkenleri içsel analiz ettiğine göre daha güvenilir sonuçlar sunmaktadır. Ancak zaman serilerini test etmeden önce I(2) seviyesinde durağan olmamasından emin olmak için birim kök testi yapılmalıdır.

Durağan olmayan ekonomik zaman serileri ile yapılan çalışmalar "sahte regresyon" (spurious regressions) problemine neden olabilmektedir. Sahte regresyonlar durumunda R2 ve t-istatistiği anlamlı olabilir. Ancak elde edilen sonuçlar, güvenilebilir olmayacaktır (Baraldi ve Enders, 2010). Bu sorunun giderilmesi için ADF (Genişletilmiş Dickey-Fuller Birim Kök Testi) ve PP (Phillips-Perron Birim Kök Testi) testleri uygulanmıștır. Dickey-Fuller birim kök testi hata terimlerinin istatistiki olarak bağımsız olduklarını ve sabit varyans farz eder. Genişletilmiş Dickey Fuller testi (ADF), modele 
gecikmeli değerler ekleyerek Dickey-Fuller testini otokorelasyon problemine karşı düzeltmiștir.

Durağanlık analizi sonrası ARDL denklemlerinin belirlenmesi gerekmektedir. Genelleştirilmiş ARDL (p,q) modeli aşağıdaki denklemle ifade edilebilir;

$$
Y_{t}=\gamma_{0 i}+\sum_{i=1}^{p} \delta_{i} Y_{t-i}+\sum_{i=0}^{q} \beta_{i}^{\prime} X_{t-i}+\varepsilon_{i t}
$$

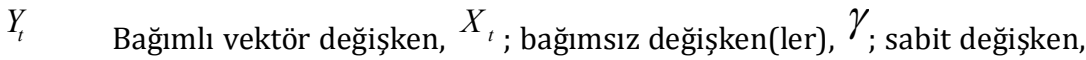
$i=1, \ldots, k ; p($ Bağımlı değişkenler için $), q($ eksojen değişkenler için $)$; optimum gecikme sayısı, $\varepsilon_{i t}$; hata terimi,

Daha önce bahsedildiği gibi, bu çalışmada ARDL modelleri bu konuda yapılan önemli araștırmalara dayanarak hazırlanmıștır. Kullanılacağımız denklem ((1) denklem) için ARDL modeli aşağıdaki gibi olacaktır:

$$
\operatorname{sgsyih}_{t}=a+\sum_{i=1}^{p} b_{i} \text { Vgsyih }_{t-i}+\sum_{i=1}^{q_{1}} c_{i} \text { Vtud }_{t-i}+\sum_{i=1}^{q_{2}} d_{i} \operatorname{Vtuo}_{t-i}+\alpha_{1} \text { gsyih }_{t-i}+\alpha_{2} t u d_{t-i}+\alpha_{3} t u o_{t-i} u_{t}
$$

$\alpha_{1}, \alpha_{2}, \alpha_{3}$ Denklemin katsayıları ve $\varepsilon_{0}$ beyaz gürültüdür. *

Sınır Testi ile ilgili eș bütünleșme gösteren katsayıları için $\mathrm{H}_{0}$ ve $\mathrm{H}_{1}$ hipotezler aşağıdaki gibi belirlenmektedir:

Ho: $\alpha_{1}=\alpha_{2}=\alpha_{3}=0$ GSYH ile (UDTS ve UÖST) arasında uzun dönem ilişki yoktur. $\mathrm{H}_{1}: \alpha_{1}=\alpha_{2}=\alpha_{3} \neq 0$ GSYH ile (UDTS ve UÖST) arasında uzun dönem ilişki vardır.

Veriler mevsimsel olduklarına göre Moving Average yöntemi ile mevsimsellikten arındırılmıștır. Verilerin performansına göre logaritmik veya normal hali kullanılmıştır. Aynı şekilde performansa ve istatistik olarak anlamlılık esasına göre trendli veya trendsiz fonksiyonları kullanılmıştır.

ARDL modelinin yapısında Birim Kök Testi gerekmese de değișkenlerden ikinci farklılıklarda durağan olmamasına dikkat edilmelidir. Bu amacın doğrultusunda Genişletilmiş Dickey-Fuller ( $A D F$ ) ve Phillip Perron $(P-P)$ testleri dikkate alınacaktır.

\section{Araştırma Bulguları} almaktadır.

Çalışmada ele aldığımız G7 ülkeleri sonucu aşağıdaki ülkeler bazında yer

\section{III.1. ABD Kısa ve Uzun Dönem Test Sonuçları}

2008 yllında yaşanan Mortgage Krizi nedeniyle ABD testini krizden önce ve krizden sonra şeklinde iki döneme bölerek test etmek daha doğru sonuçlara ulaşmamızı sağlayabilmektedir. Bu nedenle birinci dönemde 2000q1-2007q4 ve 2008q1-2017q04 olarak test edilecektir. Birinci dönemde gözlem sayımız yeterli olmayacaktır ancak genel anlamda açılklayıcı olacaktır.

\footnotetext{
${ }^{*}$ H.Pesaran (Microfit 5 kılavuzunda denklem (21.168)) açıkladığı gibi hata terimi sıfır ile -2 arasında bir değer almalıdır $0 \mathrm{f} \quad E C M_{-1} \mathrm{f}-2$. Bir basit ARDL(1,1) denklemini göz önüne bulundurulursak; $Y=\alpha+\beta * Y(-1)+\gamma^{*} X+\lambda * X(-1)$ varsayllırsa; $-(1-\beta)=E C M_{-1}$ yani $-1 \mathrm{p} \beta \mathrm{p}+1$ olmalıdır.
} 
Tablo 1: ABD verileri için Birim Kök Testi

\begin{tabular}{|c|c|c|c|c|c|c|}
\hline \multirow[b]{2}{*}{ DEĞİŞKEN } & \multicolumn{3}{|c|}{ "Genişletilmiş Dickey-Fuller (ADF) } & \multicolumn{3}{|c|}{ Phillips-Perron (PP) } \\
\hline & SABİTLİ & $\begin{array}{l}\text { SABITLII- } \\
\text { TRENDLI } \\
\end{array}$ & $\begin{array}{l}\text { SABİTSIZ- } \\
\text { TRENDSIZ }\end{array}$ & SABİTLİ & $\begin{array}{l}\text { SABITLI- } \\
\text { TRENDLI }\end{array}$ & $\begin{array}{l}\text { SABITSIZ- } \\
\text { TRENDSIZ }\end{array}$ \\
\hline GSYIH & $\begin{array}{l} \\
0.644 \\
\end{array}$ & -1.689 & 5.204 & 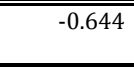 & $\begin{array}{l}-1.805 \\
\end{array}$ & 5.204 \\
\hline TUDTS & -0.658 & -2.778 & 0.613 & -0.684 & -2.820 & 0.626 \\
\hline TUOTS & $\begin{array}{l}- \\
7.706^{* * *} \\
\end{array}$ & $-5.518^{* * *}$ & 3.204 & $-7.003^{* * *}$ & $-5.109 * * *$ & 1.761 \\
\hline$\Delta$ GSYİH & $\begin{array}{l} \\
6.835^{* * *}\end{array}$ & $-6.737^{* * *}$ & $-5.316^{* * *}$ & $-6.910^{* * *}$ & $-6.817^{* * *}$ & $-5.371^{* * *}$ \\
\hline$\Delta$ TUDTS & $8.753^{* * *}$ & $-8.731^{* * *}$ & $-8.742^{* * *}$ & $-8.745^{* * *}$ & $-8.723^{* * *}$ & $-8.732^{* * *}$ \\
\hline$\Delta$ TUOTS & $\begin{array}{l}- \\
4.354^{* * *} \\
\end{array}$ & $-5.417^{* * *}$ & $-3.980^{* * *}$ & $-4.575^{* * *}$ & $-5.873^{* * *}$ & $-3.990^{* * *}$ \\
\hline
\end{tabular}

Not: ${ }^{* *}{ }^{*} e^{* * *}$ straslyla \%10, \%5 ve \%1 anlamlllk düzeyini ifade etmektedir.

Birim kök test sonuçlarına göre mevsimsellikten arındırılmıș logaritmik GSYİH birinci fakında (I(1)), TUOTS seviyesinde I(0) ve TUDTS birinci farkında I(1) durağandır. Verilerin I(0) ve I(1) karışımında durağan olduklarını göstermektedir.

\begin{tabular}{|c|c|c|c|}
\hline \multicolumn{4}{|c|}{ MODEL ARDL $(1,3,3)$} \\
\hline \multicolumn{2}{|c|}{ ESŞBÜTÜNLEŞİK KATSAYILARI } & \multicolumn{2}{|c|}{ UZUN DÖNEM KATSAYILARI } \\
\hline$\Delta$ TUDTS & -0.076 & TUDTS & $1.154^{* *}$ \\
\hline $\mathrm{ATUDTS}_{-1}$ & $-0.165^{* * *}$ & TUOTS & -0.327 \\
\hline$\Delta$ TUDTS $_{-2}$ & $-0.094^{*}$ & $\mathbf{C}$ & $11.727^{* *}$ \\
\hline$\Delta$ TUOTS & 0.003 & \multicolumn{2}{|c|}{ SINIR TESTI } \\
\hline$\Delta$ TUOTS $_{-1}$ & $-00.179 * * *$ & F-istatistik değeri & $5.246^{* * *}$ \\
\hline$\Delta$ TUOTS $_{-2}$ & 0.083 & \multirow{2}{*}{\multicolumn{2}{|c|}{ SONUÇ: }} \\
\hline $\mathrm{C}$ & 1.021 & & \\
\hline $\mathrm{EC}_{\mathrm{t}-1}$ & $-0.087^{* *}$ & \multicolumn{2}{|c|}{ Eşbütünleşik ve uzun dönem ilişki vardır. } \\
\hline
\end{tabular}

Not: *\%90 güvenlik arası, **\%95 güvenlik arasl, ***\%99 güvenlik arası, Parantez arası T-statik, köşeli parantez olasilık oranı.

Tablo 2. ABD İkinci Dönem (2008q1-2017q4), ARDL Test Sonuçları

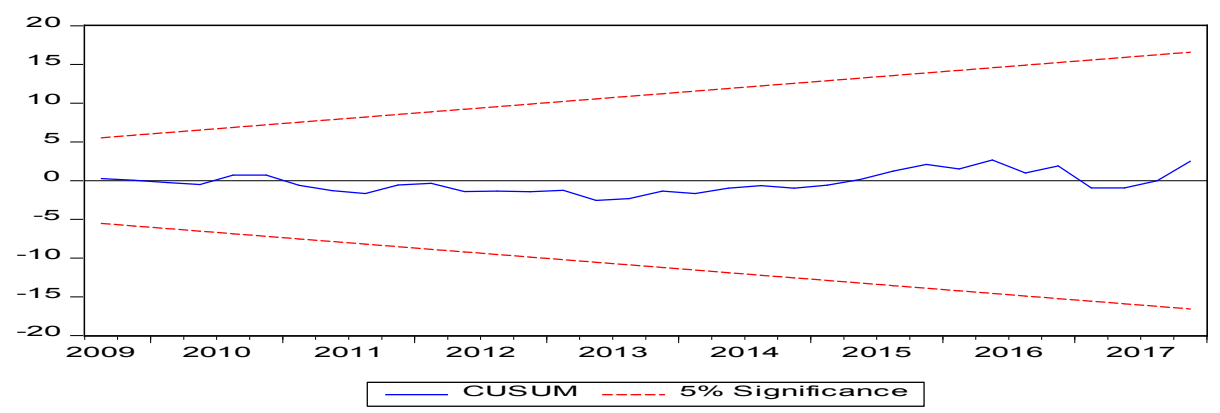

Grafik 1. ABD İkinci Dönem (2008q1-2017q4), CUSUM Grafiği 
Grafik 1 sonuçlarına göre hata terimi katsayısı (-0.087) negatif ve -2 ile 0 arasında bir değer almıştır ve bu değer istatistik olarak anlamlıdır ve sınır testi sonucunda F istatistik değerleri Pesaran kritik tablosuna göre \%99 anlamlılık düzeyinde sınır içerisindedir. Buna göre $\mathrm{H}_{0}$ reddedilmiştir. Dolaysıyla ABD'de baz alınan değișkenler arasında uzun dönem ilișki vardır.

\begin{tabular}{|c|c|c|c|c|c|c|}
\hline Lag & LogL & LR & FPE & AIC & SC & HQ \\
\hline $\mathbf{0}$ & 197.0727 & NA & $1.23 \mathrm{e}-08$ & -9703635 & -9576969 & -9657836 \\
\hline $\mathbf{1}$ & 325.8863 & 231.8646 & $3.07 \mathrm{e}-11$ & -1569432 & $-15.18765^{*}$ & -1551112 \\
\hline $\mathbf{2}$ & 337.7340 & $19.54855^{*}$ & $2.69 \mathrm{e}-11^{*}$ & $-15.83670^{*}$ & -1495004 & $-15.51611^{*}$ \\
\hline
\end{tabular}

Tablo 3. ABD Granger Nedensellik Gecikme Uzunluğu

Granger nedenselliği testi için optimum gecikme sayısı 2 belirlenmiştir.

\begin{tabular}{|c|c|c|c|}
\hline \multicolumn{4}{|c|}{ Dependent variable: LGSYIHSA } \\
\hline Excluded & Chi-sq & df & Prob. \\
\hline LTUDTSSA & 5.959 .448 & 2 & 0.0508 \\
\hline LTUOTSSA & 1.179 .758 & 2 & 0.0027 \\
\hline All & 1.419 .627 & 4 & 0.0067 \\
\hline \multicolumn{4}{|c|}{ Dependent variable: LTUDTSSA } \\
\hline Excluded & Chi-sq & df & Prob. \\
\hline LGSYIHSA & 4.536 .142 & 2 & 0.1035 \\
\hline LTUOTSSA & 1.048 .553 & 2 & 0.5920 \\
\hline All & 4.641 .490 & 4 & 0.3261 \\
\hline \multicolumn{4}{|c|}{ Dependent variable: LTUOTSSA } \\
\hline Excluded & Chi-sq & $\mathrm{df}$ & Prob. \\
\hline LGSYIHSA & 7.022 .758 & 2 & 0.0299 \\
\hline LTUDTSSA & 6.838 .276 & 2 & 0.0327 \\
\hline All & 9.324 .046 & 4 & 0.0535 \\
\hline
\end{tabular}

Tablo 4. ABD VAR-Granger-Causality İkinci Dönem (2008q1-2017q4) Test Sonucu

Belirlenen gecikme sayısı iki olarak kısa dönem test sonuçları aşağıdaki tabloda görmekteyiz. Bu tabloya göre kısa dönemde TUDTS ve TUOTS'den GSYİH'a \%95 güvenirlik düzeyinde kısa dönem ilişki ve nedensellik mevcuttur. Otokorolasyon test sonuçlarına göre kısa dönem modelimizde otokorolasyon sıkıntısı yoktur.

\begin{tabular}{|c|c|c|c|c|c|c|}
\hline Lag & LRE* stat & Df & Prob. & Rao F-stat & df & Prob. \\
\hline $\mathbf{1}$ & 13.81685 & 9 & 0.1290 & 1.601143 & $(9,78.0)$ & 0.1296 \\
\hline $\mathbf{2}$ & 12.72003 & 9 & 0.1757 & 1.463891 & $(9,78.0)$ & 0.1763 \\
\hline $\mathbf{3}$ & 13.11342 & 9 & 0.1575 & 1.512906 & $(9,78.0)$ & 0.1582 \\
\hline
\end{tabular}

Tablo 5. ABD İkinci Dönem (2008q1-2017q4) Kısa Dönem Otokorolasyon Tablosu 


\begin{tabular}{|c|c|c|c|}
\hline \multicolumn{4}{|c|}{ MODEL ARDL $(2,0,4)$} \\
\hline \multicolumn{2}{|c|}{ EŞBÜTÜNLEŞIK KATSAYILARI } & \multicolumn{2}{|c|}{ UZUN DÖNEM KATSAYILARI } \\
\hline$\Delta$ AGSYİH$_{-1}$ & -0.269 & TUDTS & 0.082 \\
\hline$\Delta$ TUDTS & 0.009 & TUOTS & $0.249^{* *}$ \\
\hline$\Delta$ TUOTS & 0.063 & $\mathbf{C}$ & $12.250^{* *}$ \\
\hline$\Delta$ TUOTS $_{-1}$ & 0.079 & \multicolumn{2}{|c|}{ SINIR TESTI } \\
\hline$\Delta$ TUOTS $_{-2}$ & -0.016 & F-istatistik değeri & $7.899^{* * *}$ \\
\hline$\Delta$ TUOTS $_{-3}$ & $-0.052^{*}$ & \multirow{2}{*}{\multicolumn{2}{|c|}{ SONUÇ: }} \\
\hline \multirow[b]{2}{*}{$\mathrm{EC}_{\mathrm{t}-1}$} & \multirow[t]{2}{*}{$-0.117^{*}$} & & \\
\hline & & \multicolumn{2}{|c|}{ Eşbütünleşik ve uzun dönem ilişki vardır. } \\
\hline
\end{tabular}

Not: *\%90 güvenlik arası, **\%95 güvenlik arası, ${ }^{* * * \% 99 ~ g u ̈ v e n l i k ~ a r a s ı, ~ P a r a n t e z ~ a r a s ı ~ T-~}$ statik, köşeli parantez olasılık oranı.

Tablo 6. ABD Birinci dönem(2000q1-2007q4); ARDL Test Sonuçları

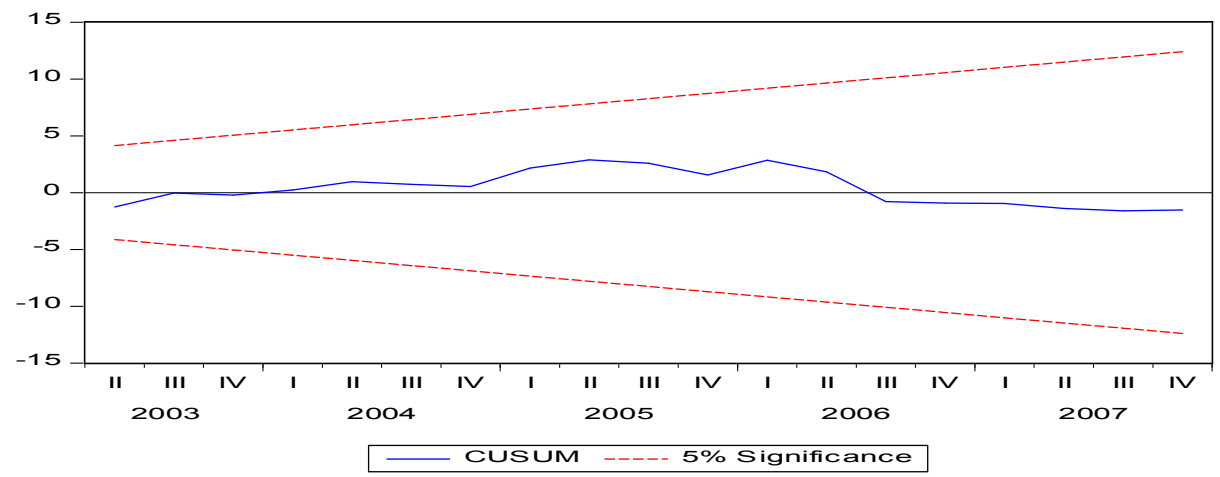

Grafik 2. ABD Birinci dönem(2000q1-2007q4); CUSUM Grafiği

Yukardaki sonuçlara göre hata terimi katsayısı $(-0.117)$ negatif ve -2 ile 0 arasında bir değer almıştır ve bu değer istatistik olarak anlamlıdır ve sınır testi sonucunda F istatistik değerleri Pesaran kritik tablosuna göre \%99 anlamlılık düzeyinde sınır içerisindedir. Buna göre $\mathrm{H}_{0}$ reddedilmiştir. ABD'de temel alınan değişkenler arasında uzun dönem ilişki vardır.

\begin{tabular}{|c|c|c|c|c|c|c|}
\hline Lag & $\log L$ & LR & FPE & AIC & SC & HQ \\
\hline $\mathbf{0}$ & 109.3101 & NA & $1.68 \mathrm{e}-07$ & -7.087 .337 & -6.947 .218 & -7.042 .512 \\
\hline 1 & 263.9294 & 268.0068* & $\begin{array}{c}\text { 1.02e- } \\
11^{*}\end{array}$ & $\begin{array}{c}-\overline{-} \\
16.79529 *\end{array}$ & $\begin{array}{c}- \\
16.23481 *\end{array}$ & $\begin{array}{c}- \\
16.61599 *\end{array}$ \\
\hline 2 & 267.6551 & 5.712832 & $1.49 \mathrm{e}-11$ & -1.644 .368 & -1.546 .284 & -1.612 .990 \\
\hline
\end{tabular}

Tablo 7. ABD Birinci Dönem(2000q1-2007q4); 
VAR-Granger-Causality için gecikme uzunluğu test sonucu: Granger nedenselliği testi için optimum gecikme sayısı 1 belirlenmiştir.

\begin{tabular}{|c|c|c|c|}
\hline \multicolumn{4}{|c|}{ Dependent variable: LGSYIHSA } \\
\hline Excluded & Chi-sq & Df & Prob. \\
\hline LTUDTSSA & 0.810278 & 1 & 0.3680 \\
\hline LTUOTSSA & 0.054764 & 1 & 0.8150 \\
\hline All & 1.675048 & 2 & 0.4328 \\
\hline \multicolumn{4}{|c|}{ Dependent variable: LTUDTSSA } \\
\hline Excluded & Chi-sq & Df & Prob. \\
\hline LGSYIHSA & 7.072570 & 1 & 0.0078 \\
\hline LTUOTSSA & 2.954042 & 1 & 0.0857 \\
\hline All & 13.25108 & 2 & 0.0013 \\
\hline \multicolumn{4}{|c|}{ Dependent variable: LTUOTSSA } \\
\hline Excluded & Chi-sq & Df & Prob. \\
\hline LGSYIHSA & 1.024602 & 1 & 0.3114 \\
\hline LTUDTSSA & 0.952161 & 1 & 0.3292 \\
\hline All & 1.063517 & 2 & 0.5876 \\
\hline
\end{tabular}

Tablo 8. ABD VAR- ABD Birinci Dönem (2000q1-2007q4); Granger-Causality İçin Test Sonucu

Belirlenen gecikme sayısı iki olarak kısa dönem test sonuçları yukardaki tabloda görmekteyiz. Bu tabloya göre kısa dönemde TUDTS ve TUOTS'den GSYİH'a kısa dönem ilişki ve nedensellik yoktur. Ancak TUOTS ve GSYIH'dan TUDTS’e kısa dönem ilișki ve nedensellik mevcuttur. Kısa dönem modelimizde otokorolasyon problemi yoktur ve sonuçları güvenilirdir.

\begin{tabular}{|c|c|c|c|c|c|c|}
\hline Lag & LRE* stat & df & Prob. & Rao F-stat & df & Prob. \\
\hline $\mathbf{1}$ & 3.219449 & 9 & 0.9550 & 0.345457 & $(9,53.7)$ & 0.9551 \\
\hline $\mathbf{2}$ & 7.808711 & 9 & 0.5535 & 0.872764 & $(9,53.7)$ & 0.5549 \\
\hline
\end{tabular}

Tablo 9. ABD Birinci dönem(2000q1-2007q4) Kısa Dönem Otokorolasyon Tablosu 


\section{III.2. İngiltere Kısa ve Uzun Dönem Test Sonuçları}

\begin{tabular}{|c|c|c|c|c|c|c|}
\hline \multirow[b]{2}{*}{ DEĞIŞKEN } & \multicolumn{3}{|c|}{ Genişletilmiş Dickey-Fuller (ADF) } & \multicolumn{3}{|c|}{ Phillips-Perron (PP) } \\
\hline & SABİTLİ & \begin{tabular}{|l} 
SABİTLİ- \\
TRENDLİ
\end{tabular} & $\begin{array}{l}\text { SABITSIZ- } \\
\text { TRENDSİ }\end{array}$ & SABİTLİ & $\begin{array}{l}\text { SABİTLİ- } \\
\text { TRENDLİ }\end{array}$ & $\begin{array}{l}\text { SABİTSIZ- } \\
\text { TRENDSİ }\end{array}$ \\
\hline GSYİH & -1.326 & -2.462 & 2.735 & -1.142 & -1.911 & 3.603 \\
\hline TUD & -1.796 & -2.565 & 0.627 & -1.796 & -2.630 & -0.167 \\
\hline -TUO & -3.800 & -0.471 & 3.852 & $-3.35^{* *}$ & -0.457 & 2.54 \\
\hline$\Delta$ GSYİH & $-4.194^{* * *}$ & $-4.22^{* * *}$ & $-2.911^{* * *}$ & $-3.64^{* * *}$ & $-3.631^{* * *}$ & $-3.009^{* * *}$ \\
\hline $\begin{array}{l}\text { TUD } \\
\end{array}$ & $-7.97^{* * *}$ & $-7.96^{* * *}$ & $-8.032^{* * *}$ & $-7.97^{* * *}$ & $-7.95^{* * *}$ & $-8.035^{* * *}$ \\
\hline$\Delta$ TUO & $-3.906^{* * *}$ & $-8.913^{* * *}$ & $-3.204^{* * *}$ & $-7.427^{* * *}$ & $-8.902^{* * *}$ & $-6.624^{* * *}$ \\
\hline
\end{tabular}

Not: ${ }^{* * *}$ ve ${ }^{* * *}$ strasiyla $\% 10, \% 5$ ve \%1 anlamlıllk düzeyini ifade etmektedir.

Tablo 10. İngiltere Verileri İçin Birim Kök Testi

Birim kök test sonuçlarına göre mevsimsellikten arındırılmıș logaritmik GSYIH ve TUDTS birinci seviyesinde (I(1)), TUOTS sabitli Phillips-Perron birim kök testinde seviyesinde I(0) durağandır ve verilerin I(0) ve I(1) karışımında durağan olduklarını göstermektedir. Yani ARDL sınır testine testi için uygundur.

\begin{tabular}{|c|c|c|c|}
\hline \multicolumn{4}{|c|}{ MODEL ARDL $(4,0,0)$} \\
\hline \multicolumn{2}{|c|}{ EŞBÜTÜNLEŞİK KATSAYILARI } & \multicolumn{2}{|c|}{ "UZUN DÖNEM KATSAYILARI } \\
\hline 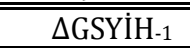 & $0.536^{* * *}$ & 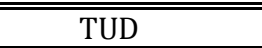 & 0.190 \\
\hline$\Delta$ GSYİH-2 & 0.181 & TUO & -0.366 \\
\hline$\Delta$ GSYİH $_{-3}$ & $-0.429 * * *$ & c & $18.721^{*}$ \\
\hline \multirow[t]{2}{*}{$\Delta$ TUD } & $0.001^{* * *}$ & \multicolumn{2}{|c|}{ SINIR TESTI } \\
\hline & & F-istatistik değeri & $5.42^{* * *}$ \\
\hline$\Delta \mathrm{TUO}$ & -0.002 & \multicolumn{2}{|c|}{ SONUÇ: } \\
\hline$\overline{E C_{\mathrm{t}-1}}$ & -0.008 & \multicolumn{2}{|c|}{$\begin{array}{l}\begin{array}{l}\text { Eşbütünleşik değil ve uzun dönem ilişki } \\
\text { yoktur. }\end{array} \\
\text { y }\end{array}$} \\
\hline $\begin{array}{l}\text { Not: } * \% 90 \text { güv } \\
\text { statik, köșeli } p\end{array}$ & $\begin{array}{l}* * \% 95 \text { güve } \\
\text { sılık oranı. }\end{array}$ & ISl, ***\%99 güvenl & intez arası $T$ - \\
\hline
\end{tabular}

Tablo 11. İngiltere Uzun Dönem ARDL Test Sonuçları

ARDL test sonuçlarına baktığımızda hata terimi -0.008 ve istatistik olarak anlamlı değildir. F istatistik sınır test değeri Pesaran tablo değerinden fazla ve \%99 güvenlilik düzeyinde anlamlıdır. Ancak eș bütünleşik olmadığına göre F değeri anlamlı olursa da $\mathrm{H}_{0}$ ret edilmemiștir ve uzun dönem ilişkileri yoktur.

Kısa dönem nedensellik analizi için optimum gecikme sayısı aşağıdaki tabloda görüldüğü gibi iki belirlenmiștir. 


\begin{tabular}{|c|c|c|c|c|c|c|}
\hline Lag & LogL & LR & FPE & AIC & SC & HQ \\
\hline $\mathbf{0}$ & -3662561 & NA & 0.000667 & 1.200776 & 1.300306 & 1.240105 \\
\hline $\mathbf{1}$ & 308.6851 & 648.7655 & $2.50 \mathrm{e}-08$ & -8990457 & -8592337 & -8833141 \\
\hline $\mathbf{2}$ & 330.5702 & $39.12794^{*}$ & $1.70 \mathrm{e}-08^{*}$ & $-9.380915^{*}$ & $-8.684206^{*}$ & $-9.105612^{*}$ \\
\hline $\mathbf{3}$ & 336.0531 & 9.304365 & $1.90 \mathrm{e}-08$ & -9274337 & -8279039 & -8881047 \\
\hline $\mathbf{4}$ & 346.3410 & 16.52297 & $1.84 \mathrm{e}-08$ & -9313364 & -8019477 & -8802087 \\
\hline $\mathbf{5}$ & 350.6226 & 6.487254 & $2.15 \mathrm{e}-08$ & -9170381 & -7577905 & -8541118 \\
\hline $\mathbf{6}$ & 358.9654 & 11.88224 & $2.24 \mathrm{e}-08$ & -9150468 & -7259402 & -8403218 \\
\hline
\end{tabular}

Tablo 12. İngiltere VAR-Granger-Causality için Gecikme Uzunluğu Test Sonucu

İki gecikme uzunluğu olan VAR-Granger nedenselliği analizine göre, TUOTS ve TUDTS'den GSYİH'a herhangi bir kısa dönem nedensellik söz konusu değildir. Ancak GSYİH ve TUOTS'den TUDTS'a güçlü kısa dönem nedensellik mevcuttur. Aynı șekilde GSYİH ve TUDTS'den TUOTS'ye de kısa dönem nedensellik söz konusudur. Otokrolasyon testine baktığımızda \%95 güvenirlik düzeyinde kısa dönem modelimiz otokorolasyon içermemektedir. Kısa dönem sonuçları güvenilirdir. Özet olarak, İngiltere'de bu değişkenleri baz alırsak, bu değişkenler arasında uzun dönem herhangi bir ilişki söz konusu değildir ve aynı şekilde GSYİH, DUOTS ve TUDTS nedeni değildir ancak tersi geçerlidir. Sonuç olarak GSYIH, DUOTS ve TUDTS üzerinde kısa dönem etki bırakmıştır.

\begin{tabular}{|c|c|c|c|}
\hline \multicolumn{4}{|c|}{ Included observations: 70} \\
\hline \multicolumn{4}{|c|}{ Dependent variable: LGSYIHSA } \\
\hline Excluded & Chi-sq & df & Prob. \\
\hline LTUDTSSA & 1.448076 & 2 & 0.4848 \\
\hline LTUOTSSA & 0.681031 & 2 & 0.7114 \\
\hline All & 2.283699 & 4 & 0.6837 \\
\hline \multicolumn{4}{|c|}{$\begin{array}{c}\text { Dependent variable: } \\
\text { LTUDTSSA }\end{array}$} \\
\hline Excluded & Chi-sq & $\mathrm{df}$ & Prob. \\
\hline LGSYIHSA & 6.485788 & 2 & 0.0391 \\
\hline LTUOTSSA & 4.211166 & 2 & 0.1218 \\
\hline All & 10.15059 & 4 & 0.0380 \\
\hline \multicolumn{4}{|c|}{ Dependent variable: LTUOTSSA } \\
\hline Excluded & Chi-sq & $\mathrm{df}$ & Prob. \\
\hline LGSYIHSA & 2.387868 & 2 & 0.3030 \\
\hline LTUDTSSA & 12.34731 & 2 & 0.0021 \\
\hline All & 12.41237 & 4 & 0.0145 \\
\hline
\end{tabular}

Tablo 13. İngiltere VAR-Granger-Causality İçin Test Sonucu

İngiltere'de baz alınan dönem ve verilerde TUDTS ve TUOTS'den GSYIH'a nedensellik mevcut değildir. Ancak TUOTS ve GSYIH'den TUDTS'a ve TUDTS ve GSYİH'dan TUOTS'ya kısa dönem nedensellik söz konusudur. Kısa dönem model otokorolasyon açısında problem içermemektedir ve sonuçlar güvenilirdir. 


\begin{tabular}{|c|c|c|c|c|c|c|}
\hline Lag & LRE* stat & df & Prob. & Rao F-stat & Df & Prob. \\
\hline 1 & 11.71382 & 9 & 0.2299 & 1.322861 & $(9,141.3)$ & 0.2301 \\
\hline 2 & 9.313566 & 9 & 0.4088 & 1.043011 & $(9,141.3)$ & 0.4091 \\
\hline 3 & 9.006122 & 9 & 0.4367 & 1.007499 & $(9,141.3)$ & 0.4369 \\
\hline
\end{tabular}

Tablo 14. İngiltere Kısa Dönem Otokorolasyon Tablosu

\section{III.3. Japonya Kısa ve Uzun Dönem Test Sonuçları}

\begin{tabular}{|c|c|c|c|c|c|c|}
\hline \multirow[b]{2}{*}{ DEĞIŞKEN } & \multicolumn{3}{|c|}{ Genişletilmiş Dickey-Fuller (ADF) } & \multicolumn{3}{|c|}{ Phillips-Perron (PP) } \\
\hline & SABİTLİ & $\begin{array}{l}\text { SABİTLI- } \\
\text { TRENDLI } \\
\end{array}$ & $\begin{array}{l}\text { SABITSIZ- } \\
\text { TRENDSIZ }\end{array}$ & SABİTLİ & $\begin{array}{l}\text { SABITLII- } \\
\text { TRENDLI } \\
\end{array}$ & $\begin{array}{l}\text { SABİTSIZ- } \\
\text { TRENDSIZ }\end{array}$ \\
\hline GSYİH & -0.771 & -2.119 & 1.728 & 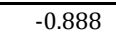 & -2.319 & 1.670 \\
\hline TUD & -0.545 & -1.78 & 0.280 & -0.545 & -1.443 & 0.280 \\
\hline TUO & 2.085 & -1.107 & 3.614 & 2.085 & -1.107 & 3.614 \\
\hline$\Delta$ GSYİH & $-7.12^{* * *}$ & $-7.077^{* * *}$ & $-6.92^{* * *}$ & $-7.030^{* * *}$ & $-6.97^{* * *}$ & $-6.85^{* * *}$ \\
\hline$\Delta$ TUD & $-7.85^{* * *}$ & $-8.36^{* * *}$ & $-7.88^{* * *}$ & $-7.85^{* * *}$ & $-8.402^{* * *}$ & $-7.89^{* * *}$ \\
\hline$\Delta$ TUO & $-7.69^{* * *}$ & $-8.256^{* * *}$ & $-3.58^{* * *}$ & $-7.69^{* * *}$ & $-8.25^{* * *}$ & $-3.580^{* * *}$ \\
\hline
\end{tabular}

Not: ${ }^{* * *}$ ve ${ }^{* * *}$ strasiyla $\% 10, \% 5$ ve \%1 anlamlllk düzeyini ifade etmektedir.

Tablo 15. Japonya Verileri İçin Birim Kök Testi

Birim kök test sonuçlarına göre mevsimsellikten arındırılmış logaritmik GSYİH, TUDTS ve TUOTS birinci seviyesinde I(1) durağan olduklarını göstermektedir. ARDL sınır testine için uygundur.

\begin{tabular}{|c|c|c|c|}
\hline \multicolumn{4}{|c|}{ MODEL ARDL $(4,2,3)$} \\
\hline \multicolumn{2}{|c|}{ "EŞBÜTÜNLEŞİK KATSAYILARI } & \multicolumn{2}{|c|}{ UZUN DÖNEM KATSAYILARI } \\
\hline$\Delta$ LGSYİH $_{-1}$ & $0.337^{* * *}$ & TUD & 0.010 \\
\hline$\Delta \mathrm{GSYİH}_{-2}$ & 0.126 & TUO & $0.09^{* * *}$ \\
\hline$\Delta$ GSYİH$_{-3}$ & $-0.222^{*}$ & $\mathrm{C}$ & $14.14^{* * *}$ \\
\hline$\Delta$ TUD & $0.027^{* *}$ & \multicolumn{2}{|c|}{ SINIR TESTİ } \\
\hline$\Delta$ TUD $_{-1}$ & $-0.027 *$ & F-istatistik değeri & 1.348 \\
\hline$\Delta$ TUO & 0.043 & \multirow{3}{*}{\multicolumn{2}{|c|}{$\begin{array}{l}\text { SONUÇ: Eşbütünleşik ancak } \\
\text { uzun dönem ilişki yoktur. }\end{array}$}} \\
\hline$\Delta \mathrm{TUO}_{-1}$ & $-0.111^{* *}$ & & \\
\hline$\Delta \mathrm{TUO}_{-2}$ & $0.067^{* *}$ & & \\
\hline $\mathrm{EC}_{\mathrm{t}-1}$ & $-0.168^{* *}$ & & \\
\hline ot: *\%90 & $* * 0<0 \Gamma$ & $* * \% 9$ & \\
\hline
\end{tabular}

Tablo 16. Japonya Uzun Dönem ARDL Test Sonuçları 
Tablo 16 sonuçlarına göre hata terimi katsayısı negatif ve -2 ile 0 arasında bir değer almıștır ve bu değer \%95 güvenirlik düzeyinde anlamlıdır. Değișkenlerden GSYIH'a pozitif ilișki vardır. Ancak sınır testi sonucunda F istatistik değerleri Pesaran kritik tablosuna göre sınır altındadır. Buna göre $\mathrm{H}_{0}$ reddedilmemiștir. Japonya'da baz alınan değişkenler arasında uzun dönem ilişki yoktur.

Kısa dönem analizi için optimum gecikme uzunluğu testini aşağıdaki tabloda görmekteyiz. Bu tablo değerleri baz alarak optimum gecikme sayısı bir belirlenmiștir.

\begin{tabular}{|c|c|c|c|c|c|c|}
\hline Lag & LogL & LR & FPE & AIC & SC & HQ \\
\hline $\mathbf{0}$ & 131.9231 & NA & $4.04 \mathrm{e}-06$ & -3.906 .762 & -3.807 .232 & -3.867 .433 \\
\hline $\mathbf{1}$ & 408.5482 & $\mathbf{5 1 9 . 7 1 9 8 *}$ & $\mathbf{1 . 2 1 e - 0 9 *}$ & $-\mathbf{1 2 . 0 1 6 6 1 *}^{*}$ & $\mathbf{- 1 1 . 6 1 8 4 9 *}$ & - \\
\hline $\mathbf{2}$ & 415.9528 & 13.23856 & $1.28 \mathrm{e}-09$ & -1.196 .827 & -1.127 .156 & -1.169 .296 \\
\hline $\mathbf{3}$ & 422.4993 & 11.10921 & $1.38 \mathrm{e}-09$ & -1.189 .392 & -1.089 .862 & -1.150 .063 \\
\hline $\mathbf{4}$ & 426.6062 & 6.595985 & $1.62 \mathrm{e}-09$ & -1.174 .564 & -1.045 .176 & -1.123 .437 \\
\hline $\mathbf{5}$ & 435.7098 & 13.79333 & $1.63 \mathrm{e}-09$ & -1.174 .878 & -1.015 .631 & -1.111 .952 \\
\hline $\mathbf{6}$ & 441.6905 & 8.517977 & $1.83 \mathrm{e}-09$ & -1.165 .729 & -9.766 .224 & -1.091 .004 \\
\hline
\end{tabular}

Tablo 17. Japonya VAR-Granger-Causality için Gecikme Uzunluğu Test Sonucu:

Optimum gecikme sayısı 1 belirlenmiştir. Bu gecikme ile test sonucunu aşağıdaki tabloda görmekteyiz.

\begin{tabular}{|c|c|c|c|}
\hline \multicolumn{5}{|c|}{ Dependent variable: LGSYIHSA } \\
\hline Excluded & Chi-sq & df & Prob. \\
\hline LTUDTSSA & 0.139626 & 1 & 0.7087 \\
\hline LTUOTSSA & 1.389102 & 1 & 0.2386 \\
\hline All & 1.766723 & 2 & 0.4134 \\
\hline \multicolumn{5}{|c|}{ Dependent variable: LTUDTSSA } \\
\hline Excluded & Chi-sq & df & Prob. \\
\hline LGSYIHSA & 0.063313 & 1 & 0.8013 \\
\hline LTUOTSSA & 0.556715 & 1 & 0.4556 \\
\hline All & 4.679331 & 2 & 0.0964 \\
\hline \multicolumn{5}{|c|}{ Dependent variable: LTUOTSSA } & Prob. \\
\hline Excluded & Chi-sq & df & 0.0067 \\
\hline LGSYIHSA & 7.353412 & 1 & 0.3805 \\
\hline LTUDTSSA & 0.769197 & 1 & 0.0190 \\
\hline All & 7.931205 & 2 & Ifin Test \\
\hline
\end{tabular}

Tablo 18. Japonya VAR-Granger-Causality İçin Test Sonucu

Kısa dönem VAR-Granger test sonuçları aşağıdaki tabloda görmekteyiz. Bu sonuçlara göre, TUDTS ve TUOTS'den GSYİH herhangi bir kısa dönem ilișki söz konusu değildir. Ancak GSYIH ve TUOTS birlikte $\% 90$ anlamlılık düzeyinde TUDTS’a kısa dönem ilişki söz konusudur. Aynı şekilde GSYIH ile TUDTS dan TUOTS'ya kısa dönem ilişki tespit edilmiștir. VAR-Grange modelimizin otokorelasyon test sonucuna baktığımızda 
otokorolasyon içermemektedir. Kısa dönem test sonuçlarımız güvenilir sonuçlardır. Otokorolasyon test sonucu aşağıdaki tabloda görmekteyiz.

\begin{tabular}{|l|l|l|l|l|l|l|}
\hline Lag & LRE* stat & df & Prob. & Rao F-stat & df & Prob. \\
\hline $\mathbf{1}$ & 10.81011 & 9 & 0.2890 & 1.215952 & $(9,151.0)$ & 0.2892 \\
\hline $\mathbf{2}$ & 10.48207 & 9 & 0.3129 & 1.177789 & $(9,151.0)$ & 0.3131 \\
\hline
\end{tabular}

Tablo 19. Japonya Kisa Dönem Otokorolasyon Tablosu

\section{III.4. Almanya Kısa ve Uzun Dönem Test Sonuçları}

Tablo 20. Almanya Verileri İçin Birim Kök Testi

\begin{tabular}{|c|c|c|c|c|c|c|}
\hline \multirow[b]{2}{*}{ DEĞIŞKEN } & \multicolumn{3}{|c|}{ Genişletilmiş Dickey-Fuller (ADF) } & \multicolumn{3}{|c|}{ Phillips-Perron (PP) } \\
\hline & SABİTLİ & $\begin{array}{l}\text { SABİTLI- } \\
\text { TRENDLI }\end{array}$ & $\begin{array}{l}\text { SABİTSIZ- } \\
\text { TRENDSIZ }\end{array}$ & SABİTLİ & $\begin{array}{l}\text { SABITTLI- } \\
\text { TRENDLI }\end{array}$ & $\begin{array}{l}\text { SABITSIZ- } \\
\text { TRENDSIZ }\end{array}$ \\
\hline GSYİH & -0.024 & -2.90 & 1.87 & -0.014 & -2.396 & 2.360 \\
\hline TUD & $-7.68^{* * *}$ & $-4.19 * * *$ & 0.89 & $-6.07 * * *$ & $-4.44^{* * *}$ & 1.42 \\
\hline TUO & $-5.40^{* * *}$ & -2.29 & 1.50 & $-4.63^{* * *}$ & -2.23 & 2.05 \\
\hline$\overline{\Delta G S Y I ̇ H}$ & $-5.36^{* * *}$ & $-5.41^{* * *}$ & $-4.94^{* * *}$ & $-5.43^{* * *}$ & $-5.46^{* * *}$ & $-4.99 * * *$ \\
\hline$\Delta$ TUD & $-2.74^{*}$ & $-7.65^{* * *}$ & $-2.46^{* * *}$ & $-5.74^{* * *}$ & $-7.95^{* * *}$ & $-5.16^{* * *}$ \\
\hline $\begin{array}{l}\text { TUO } \\
\end{array}$ & $-3.44^{* * *}$ & $-8.27^{* * *}$ & $-2.99 * * *$ & $-6.96^{* * *}$ & $-8.35^{* * *}$ & $-6.15^{* * *}$ \\
\hline
\end{tabular}

Not: ${ }^{* *}$, $e^{* * *}$ sirasiyla \%10, \%5 ve\%1 anlamlılı düzeyini ifade etmektedir.

Birim kök test sonuçlarına göre mevsimsellikten arındırılmış logaritmik GSYİH birinci seviyesinde (I(1)), TUDTS seviyesinde I(0) ve TUOTS seviyesinde I(1) durağandır ve verilerin I(0) ve I(1) karışımında durağan olduklarını göstermektedir. ARDL sınır testine testi için uygundur.

\begin{tabular}{|c|c|c|c|}
\hline \multicolumn{4}{|c|}{ MODEL ARDL $(4,3,0)$} \\
\hline \multicolumn{2}{|c|}{ EŞBÜTÜNLEȘİK KATSAYILARI } & \multicolumn{2}{|c|}{ UZUN DÖNEM KATSAYILARI } \\
\hline$\Delta$ GSYİH$_{-1}$ & $\begin{array}{c}0.38^{* * * *} \\
(3.49)\end{array}$ & TUDTS & $-0.041^{*}$ \\
\hline$\Delta$ GSYİH$_{-2}$ & $\begin{array}{l}0.143 \\
(1.17)\end{array}$ & TUOTS & $0.10^{* *}$ \\
\hline$\Delta$ GSYİH $_{-3}$ & $\begin{array}{l}0.28^{* *} \\
(2.35)\end{array}$ & TREND & $0.003^{* * *}$ \\
\hline$\Delta \mathrm{TUD}$ & $\begin{array}{l}0.011 \\
(0.86)\end{array}$ & \multicolumn{2}{|c|}{ SINIR TESTI } \\
\hline$\overline{\Delta \text { TUD }_{-1}}$ & $\begin{array}{l}0.005 \\
(0.36) \\
\end{array}$ & F-istatistik değeri & $9.186^{* * *}$ \\
\hline$\Delta$ TUD $_{-2}$ & $\begin{array}{l}0.02^{* *} \\
(2.14) \\
\end{array}$ & T-istatistik değeri & $-5.08^{* * *}$ \\
\hline$\Delta \mathrm{TUO}$ & $\begin{array}{l}-0.03^{*} \\
(-1.86) \\
\end{array}$ & & \\
\hline $\mathrm{C}$ & $\begin{array}{l}4.33^{* *} \\
(4.97)\end{array}$ & \multirow{2}{*}{\multicolumn{2}{|c|}{$\begin{array}{l}\text { Eşbütünleşik ve uzun dönem ilişki } \\
\text { vardır. }\end{array}$}} \\
\hline $\mathrm{EC}_{\mathrm{t}-1}$ & $\begin{array}{l}-0.31^{* * *} \\
(-5.08)\end{array}$ & & \\
\hline
\end{tabular}

Not: *\%90 güvenlik arası, **\%95 güvenlik arası, ***\%99 güvenlik arası, Parantez arası Tstatik, köșeli parantez olasılık oranı.

Tablo 21. Almanya Uzun Dönem ARDL Test Sonuçları 


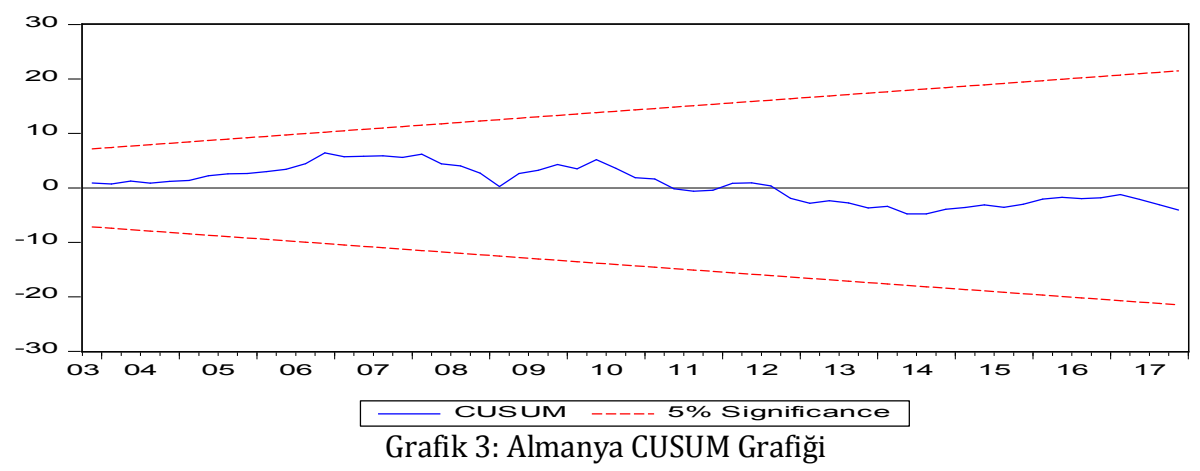

Çizelge sonuçlarına göre hata terimi katsayısı negatif ve -2 ile 0 arasında bir değer almıştır ve bu değer istatistik olarak anlamlıdır. Aynı şekilde sınır testi sonucunda $\mathrm{F}$ ve $\mathrm{T}$ istatistik değerleri Pesaran kritik tablosuna göre $\% 99$ anlamlılık düzeyinde anlamlıdır. Buna göre Ho ret, Hı kabul edilecektir. Almanya'da baz alınan değișkenler arasında uzun dönem ilişki vardır. TUDTS ile GSYİH arasındaki negatif ve TUOTS ile GSYİH arasında doğrusal ve pozitif ilişki mevcuttur. CUSUM test sonucuna göre, oluşturulan model istikrarlı ve sonuçları güvenilirdir. Kısa dönem analizi için optimum gecikme uzunluğu testini aşağıdaki tabloda görmekteyiz. Gözlem sayılar 100'den düşük olduğuna göre Schwarts ve Hannan-Quinn değerleri baz alarak optimum gecikme sayısı 1 belirlenmiştir.

\begin{tabular}{|c|c|c|c|c|c|c|}
\hline Lag & LogL & LR & FPE & AIC & SC & HQ \\
\hline $\mathbf{0}$ & 129.0395 & NA & $4.40 \mathrm{e}-06$ & -3.819 .380 & -3.719 .850 & -3.780 .051 \\
\hline $\mathbf{1}$ & 442.3923 & 588.7233 & $4.35 \mathrm{e}-10$ & -1.304 .219 & $\mathbf{- 1 2 . 6 4 4 0 7 *}$ & $\mathbf{- 1 2 . 8 8 4 8 7 *}$ \\
\hline $\mathbf{2}$ & 452.3930 & 17.88010 & $\mathbf{4 . 2 3 e - 1 0 *}$ & $\mathbf{- 1 3 . 0 7 2 5 1 *}$ & -1.237 .581 & -1.279 .721 \\
\hline $\mathbf{3}$ & 454.9988 & 4.421910 & $5.16 \mathrm{e}-10$ & -1.287 .875 & -1.188 .345 & -1.248 .546 \\
\hline $\mathbf{4}$ & 468.4690 & $\mathbf{2 1 . 6 3 4 0 8 *}$ & $4.54 \mathrm{e}-10$ & -1.301 .421 & -1.172 .033 & -1.250 .294 \\
\hline $\mathbf{5}$ & 476.1577 & 11.64955 & $4.79 \mathrm{e}-10$ & -1.297 .448 & -1.138 .200 & -1.234 .521 \\
\hline $\mathbf{6}$ & 486.9481 & 15.36803 & $4.64 \mathrm{e}-10$ & -1.302 .873 & -1.113 .766 & -1.228 .148 \\
\hline
\end{tabular}

Tablo 22. Almanya VAR-Granger-Causality Gecikme Uzunluğu Test Sonucu

Belirlenen uygun gecikme değer sayısı ile VAR-Granger-Causality test sonuçları aşağıdaki tabloda görülmektedir. 


\begin{tabular}{|c|c|c|c|}
\hline Dependent variable: LGSYIHSA & \\
\hline Excluded & Chi-sq & Df & Prob. \\
\hline LTUDSA & 0.316381 & 1 & 0.5738 \\
\hline LTUOSA & 0.336698 & 1 & 0.5617 \\
\hline All & 0.340053 & 2 & 0.8436 \\
\hline Dependent variable: LTUDSA & \\
\hline Excluded & Chi-sq & Df & Prob. \\
\hline LGSYIHSA & 1.861260 & 1 & 0.1725 \\
\hline LTUOSA & 0.252234 & 1 & 0.6155 \\
\hline All & 9.433748 & 2 & 0.0089 \\
\hline Dependent variable: LTUOSA \\
\hline Excluded & Chi-sq & Df & Prob. \\
\hline LGSYIHSA & 1.012826 & 1 & 0.3142 \\
\hline LTUDSA & 7.355725 & 1 & 0.0067 \\
\hline All & 9.735548 & 2 & 0.0077 \\
\hline
\end{tabular}

Tablo 23. Almanya VAR-Granger-Causality İçin Test Sonucu

Sonuçlarına göre kısa dönemde TUO ve TUD ile GSYİH arasında kısa dönem ilişki mevcut değildir.

\section{III.5. Fransa Kısa ve Uzun Dönem Test Sonuçları}

\begin{tabular}{|c|c|c|c|c|c|c|}
\hline \multirow[b]{2}{*}{ DEĞİŞKEN } & \multicolumn{3}{|c|}{ Genişletilmiş Dickey-Fuller (ADF) } & \multicolumn{3}{|c|}{ Phillips-Perron (PP) } \\
\hline & SABİTLI & $\begin{array}{l}\text { SABİTLİ- } \\
\text { TRENDLİ }\end{array}$ & $\begin{array}{l}\text { SABİTSIZ- } \\
\text { TRENDSIZ }\end{array}$ & SABİTLİ & $\begin{array}{l}\text { SABITLİ- } \\
\text { TRENDLİ } \\
\end{array}$ & $\begin{array}{l}\text { SABITSIZ- } \\
\text { TRENDSIZ }\end{array}$ \\
\hline GSYIH & $\begin{array}{c}- \\
0.625 \\
\end{array}$ & -2.453 & 2.471 & -1.138 & -2.30 & 3.824 \\
\hline TUD & -2.422 & -1.801 & 0.921 & -2.425 & -1.808 & 0.919 \\
\hline TUO & $\begin{array}{c}- \\
4.206^{* * *}\end{array}$ & -0.829 & 3.959 & $-4.231^{* * *}$ & -0.746 & 3.013 \\
\hline$\Delta$ GSYİH & $-4.49^{* * *}$ & $-4.429 * * *$ & $-3.605^{* * *}$ & $-4.430^{* * *}$ & $-4.362^{* * *}$ & $-3.471^{* * *}$ \\
\hline$\Delta$ TUD & $\begin{array}{c}- \\
8.228^{* * *}\end{array}$ & $-8.478^{* * *}$ & $-8.153^{* * *}$ & $-8.228^{* * *}$ & $-8.521^{* * *}$ & $-8.153^{* * *}$ \\
\hline$\Delta$ TUO & $-6.83^{* * *}$ & $-8.524 * * *$ & $-5.824 * * *$ & $-6.933^{* * *}$ & $-8.716^{* * *}$ & $-6.017^{* * *}$ \\
\hline
\end{tabular}

Not: ${ }^{* *}{ }^{*} e^{* * *}$ siraslyla \%10, \%5 ve \%1 anlamlllk düzeyini ifade etmektedir.

Tablo 24. Fransa verileri için Birim Kök Testi

Birim kök test sonuçlarına göre mevsimsellikten arındırılmış logaritmik GSYİH, TUDTS ve TUDTS birinci farkında I(1) durağandır. ARDL sınır testine testi için uygundur.

MODEL ARDL $(4,3,0)$

\begin{tabular}{|c|c|c|c|}
\hline \hline \multicolumn{2}{|c|}{ EŞBÜTÜNLEŞiK KATSAYILARI } & \multicolumn{2}{|c|}{ UZUN DÖNEM KATSAYILARI } \\
\hline \hline$\Delta$ GSYİH-1 & $0.46^{* * *}$ & TUD & -6.007 \\
\hline$\Delta$ GSYİH-2 & $0.318^{* *}$ & TUO & 0.018 \\
& & & \\
\hline
\end{tabular}




\begin{tabular}{|c|c|c|c|}
\hline$\Delta$ TUO & $0.054^{* *}$ & TREND & $1152.4^{* * *}$ \\
\hline$\Delta \mathrm{TUO}-1$ & $0.054^{* *}$ & \multicolumn{2}{|c|}{ SINIR TESTI } \\
\hline$\Delta \mathrm{TUO}_{-2}$ & $0.038^{*}$ & F-istatistik değeri & $5.292^{* *}$ \\
\hline$\Delta \mathrm{TUO}_{-3}$ & -0.004 & \multirow[b]{2}{*}{ T-istatistik değeri } & \multirow[t]{2}{*}{$-3.525^{* *}$} \\
\hline$\Delta \mathrm{TUO}_{-4}$ & 0.010 & & \\
\hline$\Delta \mathrm{TUO}_{-5}$ & $0.054^{* *}$ & \multicolumn{2}{|c|}{ SONUÇ: } \\
\hline $\mathrm{C}$ & $328657^{* * *}$ & \multirow{2}{*}{\multicolumn{2}{|c|}{ Eşbütünleşik ve uzun dönem ilişki vardır. }} \\
\hline $\mathrm{EC}_{\mathrm{t}-1}$ & $-0.158^{* * *}$ & & \\
\hline $\begin{array}{l}\text { Not: *\%90 } \\
\text { statik, köșe }\end{array}$ & $\begin{array}{l}\text { **\%95 güv } \\
\text { sllık oranı. }\end{array}$ & 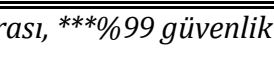 & antez arası $T$ - \\
\hline
\end{tabular}

Tablo 25. Fransa Uzun Dönem ARDL Test Sonuçları

Yukardaki çizelgede ARDL sınır testi sonuçlarına göre hata terimi -0.158 ve istatistik olarak anlamlı olarak eşbütünleşiktir. Aynı şekilde $\mathrm{F}$ ve $\mathrm{T}$ sınır istatistik değerleri \%95 güvenilir düzeyinde Pesaran tablo değerlerinde fazla olduğuna göre, Ho ret, $\mathrm{H}_{\mathrm{r}}$ kabul edilecektir ve değișkenler arasında uzun dönem ilișki vardır. Uzun dönem katsayıları istatistik anlamlı olmasa da GSYIH ile uzun donem ilişkileri vardır. TUDTS'den GSYIH'a negatif ve TUOTS'den GSYIH'a pozitif uzun dönem ilișki vardır. Uzun dönem ilişki konusunu Johansen yöntemi ile de test edilmiștir ve en az bir tane uzun dönem vektör bu teste de tespit edilmiştir. Modelin CUSUM istikrarlılık analiz aşağıda görmekteyiz.

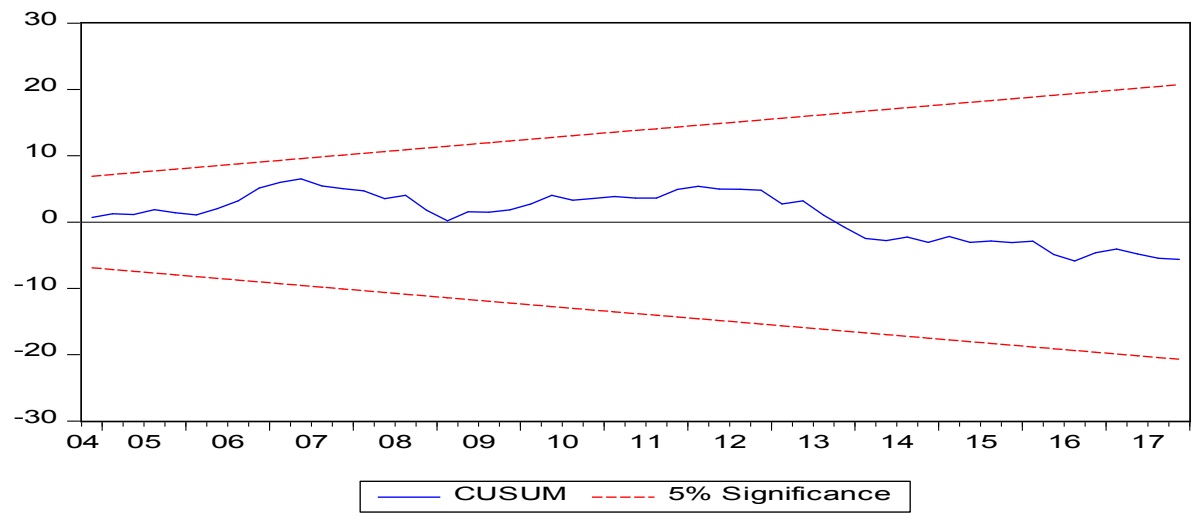

Grafik 4. Fransa CUSUM Grafiği

CUSUM test sonucuna göre \%95 anlamlılık düzeyin göre test edilen model istikrarlı ve sonuçları güvenlidir. Kısa dönem VAR-Granger nedensellik analizine için optimum gecikme uzunluğu analizi aşağıda görmekteyiz. 


\begin{tabular}{|c|c|c|c|c|c|c|}
\hline Lag & LogL & LR & FPE & AIC & SC & HQ \\
\hline $\mathbf{0}$ & 124.4571 & NA & $5.06 \mathrm{e}-06$ & -3.680 .518 & -3.580 .988 & -3.641 .189 \\
\hline $\mathbf{1}$ & 411.7541 & 539.7701 & $1.10 \mathrm{e}-09$ & -1.211 .376 & $\mathbf{-}$ & -1.195 .644 \\
\hline $\mathbf{2}$ & 429.9763 & $\mathbf{3 2 . 5 7 9 0 7} *$ & $\mathbf{8 . 3 4 e - 1 0 *}$ & $\mathbf{- 1 2 . 3 9 3 2 2} *$ & -1.169 .651 & $\mathbf{- 1 2 . 1 1 7 9 2 *}$ \\
\hline $\mathbf{3}$ & 438.6901 & 14.78712 & $8.45 \mathrm{e}-10$ & -1.238 .455 & -1.138 .925 & -1.199 .126 \\
\hline $\mathbf{4}$ & 444.5326 & 9.383405 & $9.38 \mathrm{e}-10$ & -1.228 .887 & -1.099 .498 & -1.177 .759 \\
\hline $\mathbf{5}$ & 449.6587 & 7.766730 & $1.07 \mathrm{e}-09$ & -1.217 .147 & -1.057 .900 & -1.154 .221 \\
\hline $\mathbf{6}$ & 453.1873 & 5.025642 & $1.29 \mathrm{e}-09$ & -1.200 .568 & -1.011 .461 & -1.125 .843 \\
\hline
\end{tabular}

Çizelge 26. Fransa VAR-Granger-Causality Gecikme Uzunluğu Test Sonucu

Bu tabloya göre optimum gecikme sayısı iki belirlenmiştir. Bu gecikme sayısı ile VAR-Granger sonuçları aşağıdaki tabloda özetlenmiştir.

\begin{tabular}{|c|c|c|c|}
\hline \multicolumn{5}{|c|}{ Dependent variable: LGSYIHSA } \\
\hline Excluded & Chi-sq & df & Prob. \\
\hline LTUDTSSA & 0.311527 & 2 & 0.8558 \\
\hline LTUOTSSA & 0.155370 & 2 & 0.9253 \\
\hline All & 0.354098 & 4 & 0.9861 \\
\hline \multicolumn{4}{|c|}{ Dependent variable: LTUDTSSA } \\
\hline Excluded & Chi-sq & df & Prob. \\
\hline LGSYIHSA & 3.680209 & 2 & 0.1588 \\
\hline LTUOTSSA & 9.193749 & 2 & 0.0101 \\
\hline All & 9.280690 & 4 & 0.0545 \\
\hline Excluded & Dependent variable: LTUOTSSA & Prob. \\
\hline LGSYIHSA & 0.601832 & df & 0.7401 \\
\hline LTUDTSSA & 6.469015 & 2 & 0.0394 \\
\hline All & 7.108909 & 2 & 0.1302 \\
\hline
\end{tabular}

Tablo 27. Fransa VAR-Granger-Causality İçin Test Sonucu

Bu sonuçlara göre TUDTS ve TUOTS'den GSYH'ye kısa dönem nedensellik mevcut değildir. Yalnız GSYIH ve TUOTS' de TUDTS'a kısa dönem nedensellik söz konudur. Otokorolasyon test sonucuna baktığımızda VAR-Granger modelimiz otokorolasyon içermemektedir. Sonuçları ise güvenilirdir.

\begin{tabular}{|c|c|c|c|c|c|c|}
\hline Lag & LRE* stat & df & Prob. & Rao F-stat & df & Prob. \\
\hline $\mathbf{1}$ & 12.72150 & 9 & 0.1756 & 1.441738 & $(9,141.3)$ & 0.1758 \\
\hline $\mathbf{2}$ & 14.54761 & 9 & 0.1041 & 1.659285 & $(9,141.3)$ & 0.1043 \\
\hline $\mathbf{3}$ & 13.56637 & 9 & 0.1386 & 1.542047 & $(9,141.3)$ & 0.1388 \\
\hline
\end{tabular}

Tablo 28. Fransa Kisa Dönem Otokorolasyon Tablosu 


\section{III.6. İtalya Kısa ve Uzun Dönem Test Sonuçları}

\begin{tabular}{|c|c|c|c|c|c|c|}
\hline \multirow[b]{2}{*}{ DEĞİŞKEN } & \multicolumn{3}{|c|}{ Genişletilmiş Dickey-Fuller (ADF) } & \multicolumn{3}{|c|}{ Phillips-Perron (PP) } \\
\hline & SABİTLİ & $\begin{array}{l}\text { SABITTLI- } \\
\text { TRENDLI } \\
\end{array}$ & $\begin{array}{l}\text { SABİTSIZ- } \\
\text { TRENDSIZ }\end{array}$ & SABİTLİ & $\begin{array}{l}\text { SABİTLİ- } \\
\text { TRENDLİ }\end{array}$ & $\begin{array}{l}\text { SABİTSIZ- } \\
\text { TRENDSIZ }\end{array}$ \\
\hline GSYİH & $\begin{array}{c}- \\
2.399\end{array}$ & -2.572 & 0.196 & -1.972 & -2.203 & 0.436 \\
\hline TUD & $-3.60^{* * *}$ & -2.640 & 1.233 & $-3.31^{* *}$ & -2.588 & 0.975 \\
\hline TUO & $-6.89 * * *$ & -2.366 & 2.421 & $-6.89 * * *$ & -2.632 & 2.59 \\
\hline$\Delta$ GSYİH & $-3.92^{* * *}$ & $-3.88^{* *}$ & $-3.94^{* * *}$ & $-4.04^{* * *}$ & $-4.010^{* *}$ & $-4.06^{* * *}$ \\
\hline$\overline{\Delta T U D}$ & $\begin{array}{c}- \\
7.825^{* * *}\end{array}$ & $-8.431^{* * *}$ & $-7.843^{* * *}$ & $-7.83^{* * *}$ & $-8.402^{* * *}$ & $-7.84^{* * *}$ \\
\hline $\begin{array}{l}\text { TUO } \\
\end{array}$ & $-5.78^{* * *}$ & $-8.341^{* * *}$ & $-3.048^{* * *}$ & $-5.96^{* * *}$ & $-8.341^{* * *}$ & $-4.812^{* * *}$ \\
\hline
\end{tabular}

Not: ${ }^{* *}$ ve ${ }^{* * *}$ sirasiyla \%10, \%5 ve \%1 anlamllık düzeyini ifade etmektedir.

Çizelge 29. İtalya Verileri İçin Birim Kök Testi

Birim kök test sonuçlarına göre mevsimsellikten arındırılmış logaritmik GSYIH birinci seviyesinde (I(1)), TUDTS ve TUOTS seviyesinde durağandılar ve verilerin I(0) ve I(1) karışımında durağan olduklarını göstermektedir. ARDL sınır testine testi için uygundur.

\begin{tabular}{|c|c|c|c|}
\hline \multicolumn{4}{|c|}{ MODEL ARDL $(2,0,1)$} \\
\hline \multicolumn{2}{|c|}{ EŞBÜTÜNLEŞIKK KATSAYILARI } & \multicolumn{2}{|c|}{ UZUN DÖNEM KATSAYILARI } \\
\hline \multirow[t]{3}{*}{$\Delta \mathrm{GSYIH}_{-1}$} & $0.658^{* * *}$ & TUD & 0.046 \\
\hline & & TUO & 0.003 \\
\hline & & $\mathrm{C}$ & $13.95^{* * *}$ \\
\hline \multirow[t]{2}{*}{$\Delta \mathrm{TUD}$} & 0.004 & \multicolumn{2}{|c|}{ SINIR TESTI } \\
\hline & & F-istatistik değeri & $3.004 *$ \\
\hline \multirow[t]{2}{*}{$\Delta \mathrm{TUO}$} & $0.030^{* *}$ & \multicolumn{2}{|c|}{ SONUÇ: } \\
\hline & & \multirow{2}{*}{\multicolumn{2}{|c|}{ Eşbütünleşik ve uzun dönem ilişki vardır. }} \\
\hline $\mathrm{EC}_{\mathrm{t}-1}$ & $-0.090^{* * *}$ & & \\
\hline
\end{tabular}

Tablo 30. İtalya Uzun Dönem ARDL Test Sonuçları 


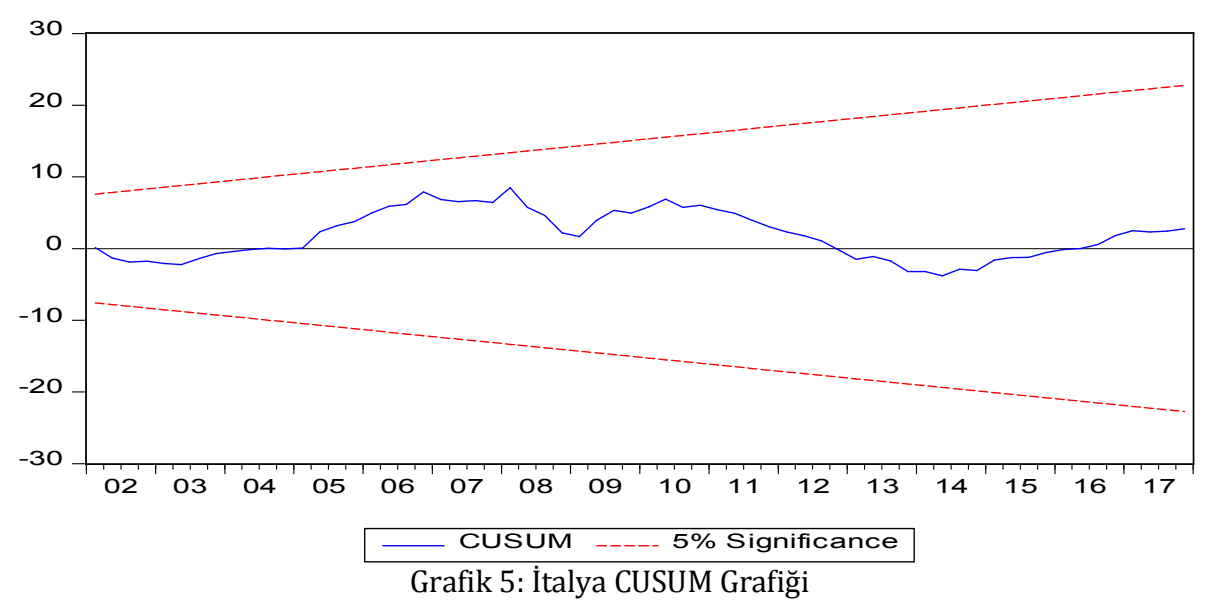

Analiz sonuçlarına göre hata terimi katsayısı negatif ve eksi iki ile sıfır arasında bir değer almıștır ve bu değer istatistik olarak anlamlıdır. Aynı şekilde, sınır testi sonucunda $\mathrm{F}$ istatistik değeri Pesaran kritik tablosuna göre $\% 90$ anlamlılık düzeyinde anlamlıdır. Buna göre Ho ret, Hı kabul edilecektir. İtalya'da baz alınan değişkenler arasında uzun dönem ilişki vardır. TUDTS ile GSYİH arasındaki pozitif ve aynı șekilde TUOTS ile GSYIH arasında pozitif ilişki mevcuttur. CUSUM test sonucuna göre oluşturulan model istikrarlı ve sonuçları güvenilirdir. Kısa dönem analizi için optimum gecikme uzunluğu testi aşağıdaki tabloda görmekteyiz.

\begin{tabular}{|c|c|c|c|c|c|c|}
\hline Lag & $\log L$ & LR & FPE & AIC & SC & HQ \\
\hline $\mathbf{0}$ & 117.1089 & NA & $6.32 \mathrm{e}-06$ & -3.457 .846 & -3.358 .316 & -3.418 .517 \\
\hline 1 & 454.6929 & 634.2487 & $3.00 \mathrm{e}-10$ & -1.341 .494 & -1.301 .682 & -1.325 .762 \\
\hline 2 & 481.6371 & 48.17300 & $1.74 \mathrm{e}$ & -1.395 .870 & $\begin{array}{c}- \\
13.26199 *\end{array}$ & $\begin{array}{c}- \\
13.68340\end{array}$ \\
\hline 3 & 56 & 27 & 10 & -1.392 .653 & -1.293 .123 & -1.353 .324 \\
\hline 4 & 493.7252 & 6.664571 & 2.11 & -1.37 & -1.248 .567 & -1.326 .828 \\
\hline 5 & 507.1134 & $20.28506 *$ & $1.88 \mathrm{e}-10$ & -1.391 .253 & -1.232 .005 & -1.328 .326 \\
\hline 6 & 518.0792 & 15.61804 & $1.80 \mathrm{e}-10$ & $\begin{array}{c}- \\
13.97210 *\end{array}$ & -1.208 .103 & -1.322 .485 \\
\hline
\end{tabular}

Tablo 31. İtalya VAR-Granger-Causality Gecikme Uzunluğu Test Sonucu:

VAR-Granger-Causality gecikme uzunluğu test sonucuna göre optimum gecikme sayısı 2 olarak belirlenmiştir. Kısa dönem analiz sonuçlarını aşağıdaki tabloda görmekteyiz. 


\begin{tabular}{|c|c|c|c|}
\hline \multicolumn{4}{|c|}{ Dependent variable: LLLGSYIHSA } \\
\hline Excluded & Chi-sq & df & Prob. \\
\hline LTUDTSSA & 2.092763 & 2 & 0.3512 \\
\hline LTUOTSSA & 1.624136 & 2 & 0.4439 \\
\hline All & 2.776804 & 4 & 0.5958 \\
\hline \multicolumn{4}{|c|}{ Dependent variable: LTUDTSSA } \\
\hline Excluded & Chi-sq & df & Prob. \\
\hline LLLGSYIHSA & 2.219310 & 2 & 0.3297 \\
\hline LTUOTSSA & 2.428632 & 2 & 0.2969 \\
\hline All & 5.683831 & 4 & 0.2240 \\
\hline \multicolumn{4}{|c|}{ Dependent variable: LTUOTSSA } \\
\hline Excluded & Chi-sq & df & Prob. \\
\hline LLLGSYIHSA & 5.363372 & 2 & 0.0684 \\
\hline LTUDTSSA & 0.700611 & 2 & 0.7045 \\
\hline All & 7.346647 & 4 & 0.1187 \\
\hline
\end{tabular}

Tablo 32. İtalya VAR-Granger-Causality İçin Test Sonucu

Kısa dönem VAR-Granger nedensellik analizine göre, herhangi kısa dönem nedensellik söz konusu değildir. Sadece GSYİH'de TUOTS'ya kısa dönem nedensellik tespit edilmiştir. Otokorolasyon test sonucuna göre kısa dönem sonuçları $\% 90$ güvenlik düzeyinde otokorolasyon içermemektedir ve sonuçlar güvenilirdir.

\begin{tabular}{|c|c|c|c|c|c|c|}
\hline Lag & LRE* stat & df & Prob. & Rao F-stat & df & Prob. \\
\hline $\mathbf{1}$ & 15.59124 & 9 & 0.0759 & 1.784852 & $(9,141.3)$ & 0.0761 \\
\hline $\mathbf{2}$ & 13.23703 & 9 & 0.1522 & 1.502876 & $(9,141.3)$ & 0.1524 \\
\hline $\mathbf{3}$ & 6.296988 & 9 & 0.7099 & 0.697817 & $(9,141.3)$ & 0.7100 \\
\hline
\end{tabular}

Tablo 33. İtalya Kısa Dönem Otokorolasyon Tablosu 


\section{III.7. Kanada Kısa ve Uzun Dönem Test Sonuçları}

\begin{tabular}{|c|c|c|c|c|c|c|}
\hline \multirow[b]{2}{*}{ DEĞİŞKEN } & \multicolumn{3}{|c|}{ Genișletilmiș Dickey-Fuller (ADF) } & \multicolumn{3}{|c|}{ Phillips-Perron (PP) } \\
\hline & SABİTLİ & $\begin{array}{l}\text { SABITLII- } \\
\text { TRENDLI }\end{array}$ & $\begin{array}{l}\text { SABİTSİ- } \\
\text { TRENDSIZ }\end{array}$ & SABİTLİ & $\begin{array}{l}\text { SABİTLI- } \\
\text { TRENDLİ }\end{array}$ & $\begin{array}{l}\text { SABİTSIZ- } \\
\text { TRENDSIZ }\end{array}$ \\
\hline GSYİH & $\begin{array}{c}- \\
0.457 \\
\end{array}$ & -2.699 & 3.120 & 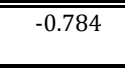 & -2.259 & $\overline{5.544}$ \\
\hline TUD & -0.067 & -2.371 & 1.129 & -0.299 & -2.510 & 0.975 \\
\hline TUO & -1.389 & -4.507 & 3.227 & -1.399 & $-4.556^{* * *}$ & 4.342 \\
\hline$\overline{\Delta \text { GSYIH }}$ & $\begin{array}{c}- \\
5.048^{* * *}\end{array}$ & $-5.003^{* * *}$ & $-3.739^{* * *}$ & $-4.86^{* * *}$ & $-4.818^{* * *}$ & $-3.680^{* * *}$ \\
\hline$\Delta$ TUD & $\begin{array}{c}- \\
7.099 * * *\end{array}$ & $-7.131^{* * *}$ & $-6.990^{* * *}$ & $-7.079^{* * *}$ & $-7.115^{* * *}$ & $-6.99^{* * *}$ \\
\hline$\Delta$ TUO & $-9.47^{* * *}$ & $-9.532^{* * *}$ & $-12.72^{* * *}$ & $-20.48^{* * *}$ & $-39.53^{* * *}$ & $-13.35^{* * *}$ \\
\hline
\end{tabular}

Not: *, *ve ${ }^{* * *}$ siraslyla \%10, \%5 ve \%1 anlamlılı düzeyini ifade etmektedir.

Tablo 34. Kanada Verileri İçin Birim Kök Testi

Birim kök test sonuçlarına göre mevsimsellikten arındırılmış logaritmik GSYIH, TUDTS ve TUOTS değişkenleri birinci seviyesinde I(1) durağan olduklarını göstermektedir. ARDL sınır testine testi için uygundur.

\begin{tabular}{|c|c|c|c|}
\hline \multicolumn{4}{|c|}{ MODEL ARDL $(2,0,0)$} \\
\hline \multicolumn{2}{|c|}{ EŞBÜTÜNLEŞİK KATSAYILARI } & \multicolumn{2}{|c|}{ UZUN DÖNEM KATSAYILARI } \\
\hline$\Delta \mathrm{GSYİH}_{-1}$ & $0,42^{* * *}$ & TUD & 0.276 \\
\hline \multirow[t]{3}{*}{$\Delta \mathrm{TUD}$} & \multirow[t]{3}{*}{$0.012^{*}$} & TUO & 0.085 \\
\hline & & $\mathrm{C}$ & $9.89^{* * *}$ \\
\hline & & \multicolumn{2}{|c|}{ SINIR TESTI } \\
\hline \multirow[t]{2}{*}{$\Delta \mathrm{TUO}$} & \multirow[t]{2}{*}{0.003} & F-istatistik değeri & $4.513^{* * *}$ \\
\hline & & \multicolumn{2}{|c|}{ SONUÇ: } \\
\hline C & 0.458 & \multirow{2}{*}{\multicolumn{2}{|c|}{$\begin{array}{l}\text { Eşbütünleşik ve uzun dönem ilişki } \\
\text { vardır. }\end{array}$}} \\
\hline $\mathrm{EC}_{\mathrm{t}-1}$ & $-0.046^{* *}$ & & \\
\hline \multicolumn{4}{|c|}{$\begin{array}{l}\text { Not: *\%90 güvenlik arası, **\%95 güvenlik arası, ***\%99 güvenlik arası, } \\
\text { Parantez arası T-statik, köșeli parantez olasıllk oranı. }\end{array}$} \\
\hline
\end{tabular}

Çizelge 35. Kanada Uzun Dönem ARDL Test Sonuçları

Çizelge 35'e göre hata terimi katsayısı negatif ve eksi iki ile sıfır arasında bir değer almıştır ve bu değer istatistik olarak anlamlıdır. Aynı şekilde sınır testi sonucunda $\mathrm{F}$ istatistik değerleri Pesaran kritik tablosuna göre \%99 anlamlılık düzeyde anlamlıdır. Buna göre Ho ret, Hı kabul edilmiștir ve Kanada'da baz alınan değişkenler arasında uzun dönem ilişki vardır. TUDTS ve TUOTS ile GSYİH arasındaki doğrusal ve pozitif ilișki mevcuttur. CUSUM test sonucuna göre oluşturulan model istikrarlıdır ve sonuçları güvenilirdir. 


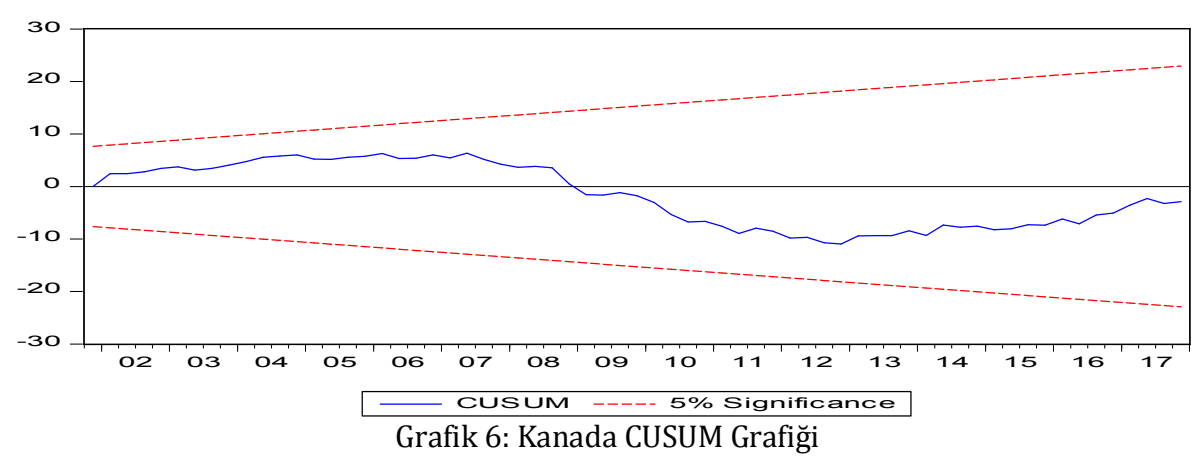

Kısa dönem analizi için optimum gecikme uzunluğu testini aşağıdaki tabloda görmekteyiz. Optimum gecikme sayısı iki belirlenmiștir.

\begin{tabular}{|c|c|c|c|c|c|c|}
\hline Lag & LogL & LR & FPE & AIC & SC & HQ \\
\hline $\mathbf{0}$ & 151.6342 & NA & $2.22 \mathrm{e}-06$ & -4.504 .067 & -4.404 .538 & -4.464 .738 \\
\hline $\mathbf{1}$ & 422.0934 & 508.1353 & $8.05 \mathrm{e}-10$ & -1.242 .707 & $\mathbf{- 1 2 . 0 2 8 9 5 *}$ & -1.226 .976 \\
\hline $\mathbf{2}$ & 439.1763 & $\mathbf{3 0 . 5 4 2 1 6} *$ & $\mathbf{6 . 3 1 e - 1 0 *}$ & $\mathbf{- 1 2 . 6 7 2 0 1 *}$ & -1.197 .530 & $\mathbf{- 1 2 . 3 9 6 7 1 *}$ \\
\hline $\mathbf{3}$ & 447.4764 & 14.08505 & $6.48 \mathrm{e}-10$ & -1.265 .080 & -1.165 .550 & -1.225 .751 \\
\hline $\mathbf{4}$ & 451.2480 & 6.057486 & $7.66 \mathrm{e}-10$ & -1.249 .236 & -1.119 .848 & -1.198 .109 \\
\hline $\mathbf{5}$ & 459.8441 & 13.02433 & $7.86 \mathrm{e}-10$ & -1.248 .012 & -1.088 .765 & -1.185 .086 \\
\hline $\mathbf{6}$ & 464.0777 & 6.029780 & $9.27 \mathrm{e}-10$ & -1.233 .569 & -1.044 .462 & -1.158 .844 \\
\hline
\end{tabular}

Çizelge 36. Kanada VAR-Granger-Causality Gecikme Uzunluğu Test Sonucu

Uygun değer gecikme sayısı bir belirlenmiștir. Bu gecikme sayısı ile Granger test sonuçlarını aşağı tabloda görmekteyiz.

\begin{tabular}{|c|c|c|c|}
\hline Dependent variable: LGSYIHSA & df & Prob. \\
\hline Excluded & Chi-sq & 2 & 0.0087 \\
\hline LTUDTSSA & 9.486785 & 2 & 0.2096 \\
\hline LTUOTSSA & 3.125372 & 4 & 0.0052 \\
\hline All & 14.78652 & \multicolumn{1}{l|}{} \\
\hline Dependent variable: LTUDTSSA & Chi-sq & df & Prob. \\
\hline Excluded & 1.752294 & 2 & 0.4164 \\
\hline LGSYIHSA & 3.313688 & 2 & 0.1907 \\
\hline LTUOTSSA & 6.058196 & 4 & 0.1948 \\
\hline All & Chi-sq & df & Prob. \\
\hline Dependent variable: LTUOTSSA & 6.569536 & 2 & 0.0374 \\
\hline Excluded & 4.241162 & 2 & 0.1200 \\
\hline LGSYIHSA & 8.813127 & 4 & 0.0659 \\
\hline LTUDTSSA
\end{tabular}

Tablo 37. Kanada VAR-Granger-Causality İçin Test Sonucu 
VAR-Granger test sonuçlarına göre kısa dönemde \%99 TUD ve TUOTS'dan GSYIH'a kısa dönem nedensellik ve ilișki mevcuttur. Aynı șekilde GSYİH ve TUDTS'dan TUOTS'ya kısa dönem nedensellik söz konusudur. \%90 güvenirlik düzeyinde Kısa dönem modelimiz otokorolasyon içermemektedir ve sonuçlar güvenilirdir.

\begin{tabular}{|c|c|c|c|c|c|c|}
\hline Lag & LRE* stat & Df & Prob. & $\begin{array}{c}\text { Rao F- } \\
\text { stat }\end{array}$ & df & Prob. \\
\hline $\mathbf{1}$ & 12.22762 & 9 & 0.2008 & 1.383371 & $(9,141.3)$ & 0.2010 \\
\hline $\mathbf{2}$ & 15.98723 & 9 & 0.0671 & 1.832733 & $(9,141.3)$ & 0.0673 \\
\hline $\mathbf{3}$ & 8.455155 & 9 & 0.4890 & 0.944048 & $(9,141.3)$ & 0.4892 \\
\hline
\end{tabular}

Tablo 38. Kanada Kısa Dönem Otokorolasyon Tablosu

\begin{tabular}{|c|c|c|c|c|}
\hline G7 & $\begin{array}{c}\text { Özel } \\
\text { Sektör }\end{array}$ & Devlet & Tüm & Tüm \\
\hline ABD & Var & Yok & $\begin{array}{l}\text { Kısa dönem } \\
\text { ilișki yoktur. }\end{array}$ & $\begin{array}{l}\text { Eşbütünleşik ve uzun dönem } \\
\text { ilișki vardır. }\end{array}$ \\
\hline İngiltere & Yok & Yok & $\begin{array}{l}\text { Kisa dönem } \\
\text { ilișki yoktur. }\end{array}$ & $\begin{array}{l}\text { Eşbütünleşik değildir ve uzun } \\
\text { dönem ilişki yoktur. }\end{array}$ \\
\hline Japonya & Yok & Yok & $\begin{array}{l}\text { Kısa dönem } \\
\text { ilișki yoktur. }\end{array}$ & $\begin{array}{l}\text { Eşbütünleşik değildir ve uzun } \\
\text { dönem ilişki yoktur. }\end{array}$ \\
\hline Almanya & Yok & Yok & $\begin{array}{l}\text { Kısa dönem } \\
\text { ilișki yoktur. }\end{array}$ & $\begin{array}{l}\text { Eşbütünleşik ve uzun dönem } \\
\text { ilișki vardır. }\end{array}$ \\
\hline Fransa & Yok & Yok & $\begin{array}{l}\text { Kısa dönem } \\
\text { ilișki yoktur. }\end{array}$ & $\begin{array}{l}\text { Eşbütünleşik ve uzun dönem } \\
\text { ilișki vardır. }\end{array}$ \\
\hline İtalya & Yok & Yok & $\begin{array}{l}\text { Kısa dönem } \\
\text { ilișki yoktur. }\end{array}$ & $\begin{array}{l}\text { Eşbütünleşik ve uzun dönem } \\
\text { ilişki vardır. }\end{array}$ \\
\hline Kanada & Yok & Var & $\begin{array}{l}\text { Kisa dönem } \\
\text { ilișki yoktur. }\end{array}$ & $\begin{array}{l}\text { Eşbütünleşik ve uzun dönem } \\
\text { ilișki vardır. }\end{array}$ \\
\hline
\end{tabular}

Tablo 39. G7 Ülkeleri Uluslararası Özel Sektör ve Uluslararası Devlet Tahvili ile GSYİH Arasındaki İlişki Yapılan Test Sonuçlarının Özeti

G7 ülkelerinin uluslararası devlet ve özel sektör tahvili büyüme ile uzun dönem hipotezi, İngiltere ve Japonya hariç diğer ülkeler hipotezi; Ho ret, $\mathrm{H}$ kabul edilmiştir. G7 ülkeleri arasında sadece ABD'de özel sektör ile GSYİH kısa dönem ilișki varken diğer ülkelerde ise kısa dönem ilişki söz konusu değildir. Dünyada en büyük ekonomiye sahip olan ABD'de hem kısa dönem, hem de uzun dönem uluslararası özel sektör tahvilleri ile ekonomi arasında bir ilişki olduğu ortaya çıkmıştır. Bunun nedeni ekonomide kamu sektörünün ağırlığı oldukça düşük olmasına karşın özel sektör üretimi, hizmeti ve tüketiminin büyük pay alması olabilir. G7 ülkeleri arasında en çok uluslararası özel sektör tahvil stokuna sahip olan ülke İngiltere'dir. Özel tüketim oranının GSYIH büyüme oranına göre daha çok yükselmesi sebebiyle borçlanma oranı aşırı yükselmiştir. Bunların yanında, hükümet harcamalarının yüksek seviyeye ulaşması ve ülkenin dünyadaki krizlerden olumsuz etkilenmesi sonucunda borçlanmaların tüketime kanalize edilmesinden kaynaklanmış olabilir. Dolayısıyla İngiltere'de hem kısa dönem hem uzun dönem herhangi bir ilişki söz konusu olmamıştır. Ancak G7 ülkeleri arasında en düşük uluslararası özel sektör tahviline sahip olan ülke Japonya'dır. Japonya'nın demografik özelliğine göre nüfusu yaşlanmaktadır. Ülkenin aşırı tasarrufa yönelmesi, iç talep 
düşüklüğü, dış ticaret fazlalığının sonucunda aşırı borçlanmaya gidilmesi ve ülke ekonomisinin performans düşüklüğü nedeniyle hem özel sektör, hem de kamu sektörünün aşırı borçlanması ve reel sektörün takviye edilmediği görülmektedir. Almanya, Fransa ve İtalya benzer şekilde uluslararası özel sektör ve uluslararası devlet tahvili hem kısa dönem hem uzun dönem ilișki bulunmamaktadır. Ancak Kanada'da kısa dönem uluslararası devlet tahvili ile ekonominin büyümesi arasında bir ilișki söz konu iken uluslararası özel sektör ile ekonominin büyümesi arasında ilișki yoktur. Uluslararası devlet tahvili ile ekonominin büyümesi arasındaki ilișkinin, ülkenin bütçe fazlalığından kaynaklı olduğu düşünebilir. Kanada'da uluslararası tahvil piyasası ile ekonominin büyümesi arasında ilișki bulunmaktadır. G7 ülkelerinde devlet sektörü ve özel sektör uluslararası tahvil ile ekonomi arasında bir ilişki bulunmazken uzun dönemde Japonya ve İngiltere hariç diğer ülkelerde ilișki bulunmaktadır. Hem aşırı borçlanması, hem de çok düşük seviyede borçlanması ekonomi için uygun bir seviye olmadığı düşünebilir. G7 ülkeleri arasında en çok uluslararası devlet tahvile sahip olan ülke Kanada'dır. Kanada'da kısa dönemde devlet tarafından ihraç edilen uluslararası tahvillerin ekonominin büyümesi ile aynı ilişside bulunduğu tek ülkedir. Diğer G7 ülkelerinin çok düşük seviyede uluslararası devlet tahvil stokuna sahip olduğu görülmektedir. Sonuç olarak hem uluslararası özel sektör tahvillerinin, hem de uluslararası devlet tahvil stoku artışının kısa dönemde ekonomi için yararlı olmadığı görünmektedir. G7 ülkeleri arasında, uzun dönemde ise İngiltere gibi aşırı yüksek seviyede uluslararası tahvil stokuna sahip olan ve Japonya gibi çok düşük seviyede uluslararası tahvil stokuna sahip olan ülkelerde uzun dönem ilişki olmadığı görülürken diğer ülkelerde uzun dönem ilișki olduğu sonucu elde edilmiștir.

\section{SONUC}

Finansal gelişme ile ekonominin büyümesi arasındaki ilişki hakkında birçok araştırmacl, ampirik çalışma sonucu pozitif ilişki olduğu görüşüne sahiptirler. Dolayısıyla tahvil piyasası finansal gelişiminin alt sistemi olarak ekonominin büyümesi ile pozitif ilişki olması beklenir. Diğer taraftan tahvil aracı bir borçlanma aracı niteliğinde olduğu için, borçların artması ekonomiyi olumsuz etkileyebilir. Haliyle ülkelerin kendilerine özgü ekonomi ve finans yapılarına göre kısa dönemde tahvil piyasası ile ekonomi arasında herhangi bir ilişki bulunmamaktadır. Bu da tahvil piyasasının bir sene ya da daha uzun dönemli vadesi bulunması özelliğinden kaynaklanabilir. Çalışma analiz sonuçlarına göre G7 ülkeleri arasında sadece ABD ülkesi özel sektör ile GSYİH kısa dönem ilișki varken diğer ülkelerde ise kısa dönem ilișki söz konusu değildir. Bunun nedeni ABD ekonomisinde kamu sektörünün ağırlığı oldukça çok az olmasına karşın özel sektör üretimi, hizmeti ve tüketiminin büyük pay alması olabilir. G7 ülkeleri arasında en çok uluslararası özel sektör tahvil stokuna sahip olan ülke İngiltere'dir. Özel tüketim oranının GSYİH büyüme oranından çok daha yüksek olması, borçlanma oranını aşırı yükseltmiş̦tir. Bunların yanında hükümet harcamalarının yüksek seviyeye ulaşması ve ülkenin dünya krizinden olumsuz etkilenmesi sonucunda borçların tüketime kanalize edilmesinden kaynaklanabilir. Dolayısıyla İngiltere için hem kısa dönem hem uzun dönem herhangi bir ilişki olmamıştır. G7 ülkeleri arasında en düşük uluslararası özel sektör tahvil sahip olan ülke Japonya'dır. Japonya'nın demografik özelliğine göre nüfusun yaşlanması durumu, ülkenin aşırı tasarrufa yönelmesi, iç talep düşüklüğü, dış ticaret fazlalığı ve bunun sonucunda aşırı borçlanmaya gidilmesi ve ülke ekonomisi performans düşüklüğü sonucunda hem özel sektör, hem de kamu sektörü aşırı borçlanması nedenleri ile reel sektörün takviye edilmediği görülmektedir. Almanya, Fransa ve İtalya'da benzer șekilde uluslararası özel sektör ve uluslararası devlet tahvili kısa dönem ilişkisi bulunmamaktadır ancak uzun dönem ilişki bulunmaktadır. Ancak 
Kanada'da kısa dönemde uluslararası devlet tahvilleri ile ekonomi arasında ilişki bulunurken uluslararası özel sektör ile ekonominin büyümesi arasında herhangi bir ilişki bulunmamaktadır. Ülkedeki bütçe fazlalığı sebebiyle uluslararası devlet tahvilleri ile ekonomi arasında ilișki bulunması olasıdır. Ayrıca uluslararası devlet ve özel sektör tahvili ile ekonominin büyümesi arasında bir ilișki bulunmaktadır. G7 ülkelerinde kısa dönemde devlet sektörü ve özel sektör uluslararası tahvilleri ile ekonomi arasında bir ilișki bulunmazken uzun dönemde Japonya ve İngiltere hariç diğer ülkelerde ilişki bulunmaktadır. Hem aşırı borçlanma, hem de çok düşük seviyede borçlanmanın ekonomi için uygun bir seviye olmadığı düşünebilir. G7 ülkeleri arasında en çok uluslararası devlet tahviline sahip olan ülke Kanada'dır. Kanada, kısa dönemde devlet tarafından ihraç edilen uluslararası tahvillerin ekonominin büyümesi ile aynı ilişkide bulunduğu tek ülkedir. Diğer G7 ülkelerinin çok düşük seviyede uluslararası devlet tahvil stokuna sahip olduğu görülmektedir.

Sonuç olarak hem uluslararası özel sektör tahvilleri, hem de uluslararası devlet tahvil stok artışının kısa dönemde ekonomi için yararlı olmadığı düşünebilir. Uzun dönemde ise İngiltere ve Japonya hariç diğer ülkelerin ekonomisine katkı sağladığı görülmektedir.

\section{KAYNAKÇA}

DEIDDA, L. G. (2006), Interaction between economic and financial development, Journal of Monetary Economics, 53: 233-248.

DEMIRGÜ-Kun, A., LEVINE, R., (2001), Financial Structure and Economic Growth: A Cros-Country Comparison Of Banks, Market and Devleopment. MIT Press.

FINK, G., HAISS, P., HRISTOOROVA, S, (2003), Bond Market and Economik Growth, IEF Working Paper, No: 49, PP:1-39

GOLSMISH, R. W., (1969), Financial Struture And Develeopment As a Subjekt For International Comparative Study, National Bureau of Economic Research, 5,09,2018, https://www.nber.org/chapters/c4417.pdf, PP: 114-123

GRAFF, M., (2001), Financial Development and Economic Growth - New Data and Emperical Analysis, METU Studies in Development, No: 28, 83-110

GURLLEY, J.G., SHOW, E.S., (1955), Financial Aspects Of Economic Develeopent,

The American Economic Review, 45(4), PP. 515-538

GÜRDAL, T., YAVUZ, H., (2015), Türkiye'de İç Borçlanma- Ekonomik Büyüme İlișkisi: 1990-2012 dönemi Analizi, Ekonomik ve Sosyal Araştırma Dergisi, 11(1), 117130

HERMES, N., LENSINK, R., (2000), Financial System Develeopment in Transition Economies, Journal Of Banking And Finance, No:24, 2000, 507-524

KENOURGOIS, D., SAMITAS, A., (2007), Financial Development and Economik Growth in Transition Economy: Evidence For Poland, Journal Of Financial Decision Making, Vol:3, NO: 1,

KING, R., G., LEVINE, R., (1993), "Finance and Growth: Schumpeter Might Be Right", The Quarterly Journal of Economics, Vol.108, No:3, PP. 717-737

LEVINE, R., LOAYZA, N., BECK, T., (2000), Financial Intermediation and Growth: Causality and Causes, Journal Of Monetary Economics, N0:46, 31-77

LEVINE, R., ZERVOS, S., (1996), Stock market devleopment and long-run Growth,

World Bank, Policy Reserch Working Paper 1582,

LUCAS, R. E. (1988): "On the mechanics of economic development," Journal of Monetary Economics, 22, 3-42.

MASSA. M., ZALDOKAS, A., (2014), "Investor Base And Corprate Borrowing: 
Evidence From International Bonds", Journal Of International Economics, No: 92, PP: 95110.

MCKINNON, R., I., (1973). Money and Capital in Economic Development, (Washington: The Brookings Institution).

PRADHAN, R. P., ZAKI, D.B, MARADANA, R. P., DASH, S, JAYAKUMAR, M., CHATTERJEE, D. (2015), Bond Market Development and Economic Growth: The G-20 Experience, Tekhne, No: 40, PP: 1-15

PAGANO, M. (1993), "Financial markets and growth: an overview", European Economic Review, 37(2-3), 613-622

PAPAIOANNOU, E., (2007), Finance and Growth a Macro Ekonomic Assesment of The Evidence From A Earupean Angle, European Central Bank, Working Paper Series No: 787

PATRICK, H., (1966), "Financial Development and Economic Growth in Underdevelopment Countries", Economic Development and Cultural Change, Vol(14), 174-189

PESARAN, M., H., SHIN, Y., SMITH, R., J., (2001), Bounds testing approaches to the analysis of level relationships, Journal of Applied Econometrics. 16: 289 - 326

https://onlinelibrary.wiley.com/doi/full/10.1002/jae.616

PESARAN, M.,H., SHIN, Y., (1998), An Autoregressive Distributed-Lag Modelling Approach to Cointegration Analysis, Econometric Society Monographs, No:31, 371-413

ROBINSON, J. (1952) The Generalisation of the General Theory, in the Rate of Interest, and Other Essays. 2nd Edition, Macmillan, London.

SCHUMPETER, J., A., (1911), The Theory of Economic Development, Harvard University Prees, Cambridge

THUMRONGVITE, P., Kim Y., Pyun, C. S., (2013), "Linking The Missing Market: The Effect Of Bond Markets On Economic Growth", International Review of Economics And Finance, Vol: 27, P.529-541

TREW, A. W.,(2005), Finance and Growth: A Ciritical Survey, Centre For Dynamic Macroeconomic Analaysis Working Paper Series, CDMA05 / 07,

ZAHEDUL ISLAM CHROWDHURY, S.M., BAYAR, Y., KILIÇ, C., (2013), "Bașlıca Makro Ekonomik Göstergelerin Gelişmekte Olan Ülkeler Endeksi Üzerindeki Etkisi”, Afyon Kocatepe Üniversitesi IIBF Dergisi, 15(2), S: 15-30

BIS, Bank For International Settlements, 25,07,2018, https://www.bis.org/ The World Bank,18,08,2018, https://www.worldbank.org/

\section{Summary}

Historical process in most of the countries shows that the opportunities provided by the financial system are strongly efficient in the development of a country. In this development, especially in today's financial system, the acceleration of the development of the bond market may provide an important break for the growth of the economy. In this study, we will try to measure this impact. For this aim, we will evaluate the bond market in terms of the government and private sector within the international framework. We will evaluate the data of G7 countries in a comparative analysis. Data's of this study based on 2000Q1-2017Q4 databases and we performed two-stage on it. Due to the seasonal, limited and long term data's, we examine the ARDL model which based on Pesaran and Shin (1999) theory. For short-term analysis, we used VAR-Granger-Causality (Block Exogeneity Wald Tests) model. Many researchers have found that there is a positive relationship between the financial development and the growth of the economy.Therefore, it is expected that there will be a positive relationship with the growth of the economy as a subsystem of 
the bond market financial development. On the other hand, as the bond instrument is a debt instrument, overcoming the debts may adversely affect the economy. Therefore, there is no relation between the bond market and the economy in the short term according to the specific economic and financial structures of the countries. This may be due to the fact that the bond market has a maturity of one year or more. As a result, the international bond development of G7 countries did not contribute to the national economy in the short term; but long-term this contribution was efficient into the economy, except Japan and the United Kingdom. 